\title{
Testing and numerical modelling of S960 ultra-high strength steel angle and channel section stub columns
}

\author{
Fangying Wang a , Ou Zhao *a, Ben Young ${ }^{\mathrm{b}}$ \\ a School of Civil and Environmental Engineering, Nanyang Technological University, Singapore \\ ${ }^{\mathrm{b}}$ Department of Civil and Environmental Engineering, The Hong Kong Polytechnic University, Hong \\ Kong, China (Formerly, Department of Civil Engineering, The University of Hong Kong, Pokfulam \\ Road, Hong Kong, China) \\ *Corresponding author, Email: ou.zhao@ntu.edu.sg
}

\begin{abstract}
A comprehensive experimental and numerical study of the cross-sectional compressive behaviour and resistances of press-braked S960 ultra-high strength steel (UHSS) angle and channel section stub columns is reported in this paper. The experimental study was carried out on four equal-leg angle sections and eight plain channel sections, and comprised material testing, initial local geometric imperfection measurements and 18 stub column tests. The experimental setups, procedures and key observations were fully presented. The experimental study was then supplemented by a finite element (FE) simulation programme, in which FE models were firstly developed to replicate the test structural responses and subsequently used to generate further numerical data over a wide variety of cross-section sizes. It is worth noting that the current international standards established in Europe, America and Australia/New Zealand only cover the design of structural members with material grades up to S700, and thus the examined S960 UHSS angle and channel section stub columns are out of the scope of the existing design standards. In this study, the experimentally and numerically acquired data was adopted to assess the applicability of the codified provisions and formulations to the design of S960 UHSS angle and channel section stub columns. The assessment results generally indicated that the current European code leads to overall consistent and accurate predictions of cross-section compression resistances, but with many overestimated predicted resistances for S960 UHSS channel section stub columns, while the American and Australian/New Zealand standards yield unduly scattered design cross-section compression resistances, with unsafe and overly conservative predicted resistances respectively for S960 UHSS channel section stub columns and slender angle section stub columns. Revised codified design rules were also proposed, and shown to yield safe, accurate and consistent design cross-section compression resistances for S960 UHSS angle and channel section stub columns.
\end{abstract}

Keywords: Angle sections; Channel sections; Design standards; Numerical modelling; Pressbraked; Revised design provisions; S960 ultra-high strength steel; Stub column tests

\section{Introduction}

High strength steels (HSS) with the nominal yield stresses greater than $460 \mathrm{MPa}$ feature superior strength-to-weight ratios, and thus offer the possibility of designing structural components with small dimensions and light weights. This would greatly facilitate the assembly of structural members during construction and the disassembly of them after use, making high strength steels a desirable and promising material, particularly for relatively heavy (long-span and high-rise) structures [1,2]. Ultra-high strength steel (UHSS) Grade S960, with the nominal yield stress of $960 \mathrm{MPa}$, is currently mainly used in the automotive industry; for 
example, the load-bearing components of container trailers and heavy lifting systems of truckmounted cranes are typically made of S960 ultra-high strength steels. However, its application in construction engineering is rather limited, principally due to the lack of adequate design rules, as the existing international standards only cover the design of high strength steel structures with material grades up to S690. Besides, research into S960 UHSS structural members remained scarce, with the only studies reported by Li et al. [1], Shi et al. [3] and Ma et al. [4] on welded box section, welded I-section and cold-formed square hollow section stub columns. This thus prompts a thorough research project being performed by the authors, aimed at examining the behaviour and resistances of different types of S960 UHSS structural members of varying cross-section shapes and devising precise and efficient design rules for them.

This paper reports an experimental and numerical study of the cross-sectional compressive behaviour and capacities of press-braked S960 UHSS angle and channel section stub columns. The experimental investigation was performed on four equal-leg angle sections and eight plain channel sections, and comprised material tensile flat and corner coupon tests, initial local geometric imperfection measurements and a total of 18 stub column tests. The acquired experimental results were afterwards adopted in a numerical simulating programme for the purpose of validating finite element (FE) models, and parametric studies were then carried out using the validated FE models, to derive further numerical data over a wide variety of crosssection sizes. The derived experimental and numerical data was utilised to assess the applicability of the provisions and formulations, established in the European code EN 1993-112 [5], North American specification AISI S100 [6] and Australian/New Zealand standard AS/NZS 4600 [7], to the design of S960 UHSS angle and channel section stub columns. Revised codified design rules were also proposed.

\section{Experimental study}

\subsection{Press-braked angle and channel section stub column specimens}

The test angle and channel section stub column specimens were press-braked from the same batch of ultra-high strength steel grade S960 sheets with the nominal material thickness of 6 $\mathrm{mm}$ and yield stress of $960 \mathrm{MPa}$. The S960 ultra-high strength steel sheets [8] were manufactured following a series of standard quenching and tempering processes, with the mechanical properties satisfying with the requirements specified in EN 10025-6 [9] for Grade S960 QL steel and the chemical compositions shown in Table 1. The schematic diagram of the press brake setup is shown Fig. 1(a), including a V-shaped die, on which the S960 ultra-high strength steel sheets are placed, and a punch, used to bend the sheets into the required crosssection shapes. It is worth noting that S960 ultra-high strength steel characterises brittle nature, and the minimum bend radii are required to be 3.0 and 2.5 times the sheet thickness for pressbraking along and perpendicular to the sheet rolling direction, respectively [8]. Failure to comply with the minimum bend radius requirements may lead to cracks along the bend line of the specimen - see Fig. 1(b) displaying a press-braked S960 UHSS channel section stub column specimen with the inner corner radius equal to 1.5 times the sheet thickness. In the present testing programme, all the specimens were press-braked from $6 \mathrm{~mm}$ thick S960 UHSS sheets, with the bend lines perpendicular to the sheet rolling direction and the nominal inner corner radii of $15 \mathrm{~mm}$ (i.e. 2.5 times the sheet thickness); flawless and rather smooth corner surfaces were achieved for all the specimens, a typical example of which is depicted in Fig. 1(c). 
A total of four equal-leg angle sections (A $60 \times 6$, A $80 \times 6$, A $100 \times 6$ and A $140 \times 6$ ) and eight plain channel sections (C $70 \times 40 \times 6$, C $80 \times 45 \times 6$, C $80 \times 55 \times 6$, C $100 \times 45 \times 6$, C $100 \times 60 \times 6$, C $120 \times 45 \times 6, \mathrm{C} 120 \times 70 \times 6$ and $\mathrm{C} 120 \times 90 \times 6$ ) were fabricated and examined in the testing programme. The cross-section identifier is composed of a letter " $\mathrm{A}$ " (or " $\mathrm{C}$ ") designating an angle section (or a channel section) and the nominal dimensions of the cross-section in millimetres, i.e. outer leg width $B \times$ wall thickness $t$ for angle section and outer web width $B_{w}$ $\times$ outer flange width $B_{f} \times$ wall thickness $t$ for channel section - see Fig. 2 . The nominal stub column lengths $L$ were chosen to be equal to 2.5 times the nominal outer leg widths for equalleg angle sections, but 2.5 times the mean nominal outer widths of webs and flanges for channel sections, which fell within the range of stub column length specified in Ziemian [10]. Geometric measurements on the press-braked S960 UHSS angle and channel section stub column specimens were carefully taken, with the average measured key parameters respectively presented in Tables 2 and 3 .

\subsection{Material testing}

The material properties of the press-braked S960 UHSS angle and channel sections were determined through tensile coupon tests. The press-braking process is known to result in strength enhancements at the corner portions of the sections [11], and therefore the material properties of both the flat and corner portions were measured. The variation of the material properties among different angle and channel sections was deemed to be rather small, since all the cross-sections were press-braked from the same batch of S960 UHSS sheets using the same punch. Tensile coupons were therefore only extracted from two representative angle sections (A $60 \times 6$ and A $140 \times 6$ ) and two representative channel sections (C $70 \times 40 \times 6$ and C $120 \times 90 \times 6$ ), with the locations shown in Fig. 2. The labelling system of each tensile coupon comprises its cross-section identifier and location within the cross-section (with "L", "W", "F" and "C" respectively representing angle leg, channel web, channel flange and corner). Moreover, one flat coupon was also extracted from the S960 UHSS virgin sheet in the transverse direction, i.e. the direction perpendicular to the sheet rolling direction, and labelled as "VS". The geometric sizes of both the flat and corner tensile coupons complied with the requirements given in ASTM E8M-15 [12], and all the coupons were machined with a $12 \mathrm{~mm}$ parallel width and a $50 \mathrm{~mm}$ gauge length. The tensile coupon tests were displacement-controlled and performed in an INSTRON $250 \mathrm{kN}$ testing machine. A constant displacement rate of 0.05 $\mathrm{mm} / \mathrm{min}$ was used up to the nominal yield stress of $960 \mathrm{MPa}$, while a higher rate of $0.4 \mathrm{~mm} / \mathrm{min}$ was adopted for the post-yield stage. Static loads were obtained by pausing the tests for $100 \mathrm{~s}$ to allow stress relaxation to occur near the nominal yield stress and ultimate tensile stress, following the procedures recommended in Huang and Young [13]. The material tensile coupon test setup is depicted in Fig. 3, in which two strain gauges are affixed to the mid-height of the coupon to record the tensile strains in the longitudinal direction and an extensometer is mounted onto the necked part of the coupon to measure the elongation [13-16].

The full stress-strain curves derived from the material testing are plotted in Fig. 4, where both the flat and corner coupons display relatively rounded material responses. Therefore, the material yield stresses are given as the $0.2 \%$ proof stresses $[1,4,17-19]$. The measured material properties for the tested flat and corner coupons are summarised in Table 4, where $E$ is the Young's modulus, $f_{y}$ is the yield stress, $f_{u}$ is the ultimate tensile stress, $\varepsilon_{u}$ is the strain at the ultimate tensile stress and $\varepsilon_{f}$ is defined as the strain calculated over the gauge length of $50 \mathrm{~mm}$ at fracture. It is evident in Fig. 4 and Table 4 that the process of press-braking results in a moderate increase in both $f_{y}$ and $f_{u}$ at the corner regions of the specimens, though accompanied by a reduction in ductility (reflected by $\varepsilon_{u}$ and $\varepsilon_{f}$ ). It can also be observed that the material 
properties of the flat regions of the press-braked specimens remained essentially unaltered in comparison with those of the virgin sheets, because the coupons in the flat regions were extracted some distances away from the corners of the sections. These observations were similar to the findings of material tensile coupon tests conducted on cold-formed angle sections by Popovic et al [20].

\subsection{Measurements on initial local geometric imperfections}

Initial geometric imperfections were induced into thin-walled steel sections during the process of manufacturing, transportation and handling, and may affect their structural responses [2123]. The Initial local geometric imperfection of each angle (and channel) section stub column specimen was therefore measured. A measuring setup similar to that described in [23] was employed, as shown in Fig. 5, where the specimen is mounted on a CNC router table, and LVDTs, with their magnet stands sitting at the arm of the CNC router, are moved longitudinally along the specimen to record the local deviations. For each angle section specimen, measurements were made by recording the readings from four LVDTs, with two offset $5 \mathrm{~mm}$ from the corner and another two offset $5 \mathrm{~mm}$ from the flange tips, as shown in Fig. 5(a), whilst for each of the channel section specimens, three LVDTs were utilised to record the initial local geometric imperfections along the centrelines of the internal web and two outstand flanges, as presented in Fig. 5(b). The initial local geometric imperfections of each plate element were taken as the derivations from a linear regression line (or surface) fitted to the corresponding measured data set $[2,24]$, with the maximum deviations denoted as $\omega_{f 1}$ and $\omega_{f 2}$ for flanges of channel section (or legs of angle section) and $\omega_{w}$ for channel web, while the initial local geometric imperfection of the specimen $\omega_{0}$ is defined as the largest derivation from all the constituent plate elements. Tables 2 and 3 report $\omega_{f 1}, \omega_{f 2}, \omega_{w}$ and $\omega_{0}$ for the press-braked S960 UHSS angle and channel section stub column specimens, respectively.

\subsection{Stub column tests}

A total of 18 stub column tests were carried out in the experimental programme to examine the local buckling behaviour and cross-sectional resistances of S960 UHSS angle and channel sections in compression. Specifically, each of the four angle sections was examined by two repeated stub column tests, whilst one stub column test was conducted on each of the eight channel sections and repeated tests were also carried out on two representative channel sections C $70 \times 40 \times 6$ and $\mathrm{C} 120 \times 90 \times 6$. All the specimens were tested under axial compression in an INSTRON $2000 \mathrm{kN}$ capacity servo-controlled hydraulic testing machine. The setups of angle and channel section stub column tests are respectively displayed in Fig. 6(a) and 7(a), where three LVDTs are vertically placed to measure the axial end shortening of the specimen and strain gauges are affixed to the mid-height of the specimen at both the flat faces and corners to record the average compressive stains along the longitudinal direction. The ends of the specimens were milled flat and stiffened in the tests in order to attain fixed-ended boundary conditions and avoid any premature end failure. Specifically, the two ends of each angle section specimen were clamped tightly by fixing three $20 \mathrm{~mm}$ thick steel plates to position [18], as depicted in Fig. 6(b). For channel section stub columns, high strength bolts were tightened between the inner faces of the flanges near the ends and G-clamps were also clamped onto the outer faces of the flanges, as depicted in Fig. 7(b) [18]. All the stub column tests were displacement-controlled at a constant loading rate of $0.2 \mathrm{~mm} / \mathrm{min}$. Similar in spirit to tensile coupon tests, static loads were obtained by pausing the tests for $100 \mathrm{~s}$ near the ultimate loads to allow for stress relaxation $[14,15,25]$. 
It is worth noting that the LVDT readings contain both the end shortening of the stub column specimen and the deformation of the end platens of the testing machine. The end-shortening of the stub column specimen was thus obtained by eliminating the deformation of the end platens of the testing machine from the LVDT measurements based on the strain gauge readings $[26,27]$. This was achieved by assuming that the end platen deformation was proportional to the applied load and shifting the load-end shortening curve derived from the LVDTs such that its initial slope matched that obtained from the strain gauges. The load-axial end shortening curves are summarised in Fig. 8 and Fig. 9 for the tested press-braked S960 UHSS angle and channel section stub columns, respectively, with the ultimate loads $N_{u, t e s t}$ and axial end shortenings at the ultimate loads $\delta_{u}$ reported in Table 5 and Table 6 . The failure modes of the press-braked S960 UHSS angle section stub column specimens, as shown in Fig. 10(a), feature both torsional deformation and flexure about the major principal axes, i.e. flexural-torsional buckling mode, though torsion is significantly more evident compared to major-axis flexure. All the channel section stub column specimens failed by local buckling, characterising a classic 'in-out' deformed mode at mid-height, as evidently shown in Fig. 10(b).

\section{Finite element modelling}

\subsection{General}

A numerical modelling programme was performed in conjunction with the laboratory testing programme. Numerical models were developed, using the general purpose FE analysis package ABAQUS [28], aimed at (i) replicating the test compressive behaviour of the S960 UHSS angle and channel section stub column specimens and (ii) performing parametric analyses to derive further FE results over a wide variety of cross-section sizes.

\subsection{Development of FE models}

Each angle or channel section stub column FE model was developed using the S4R shell element [28] and based on the measured geometric dimensions. With regard to the geometric modelling of the press-braked angle (or channel) section stub column specimens, the element size was determined following a prior mesh sensitivity study considering both the numerical accuracy and computational efficiency; a uniform mesh with both the element length and width equal to the cross-section thickness $t$ was adopted for the flat regions of the stub column FE models, while a finer mesh with at least 10 elements was utilised to discretise the corners of the FE models. The measured stress-strain curves from the tensile flat and corner coupon tests, known as the engineering material responses, were converted into the true stress-true plastic strain curves before assigned to the respective flat and corner parts of the FE models [28]. Previous researchers [29,30] have conducted membrane and bending residual stress measurements on cold-formed high strength steel sections and concluded that the magnitude of the membrane residual stresses was very small compared to that of the bending residual stresses and thus the influence of the membrane residual stresses on the behaviour of coldformed high strength steel section members was negligible. The bending residual stresses, which were evidenced by the longitudinal curvature of the tensile coupons when they were extracted from the cold-formed high strength steel sections, were approximately reintroduced during tensile testing as the coupons were returned to their straight configuration under the application of tensile loading [29,30]. Therefore, the effect of the bending residual stresses is considered to be inherently presented into the measured material stress-strain responses. On this basis, and coupled with the fact that the studied local buckling behaviour is generally 
insensitive to residual stresses, explicit measurements and modelling of both membrane and bending residual stresses in press-braked (cold-formed) S960 high strength steel angle and channel section stub columns were thus deemed unnecessary. For the ease of setting boundary conditions, each of the two end sections of the stub column FE models was firstly coupled to a reference point, positioned at the centroid of the cross-section; then, one reference point was only allowed to have longitudinal translation, whilst the other one was fully restrained against any translation and rotation, to attain the fixed-ended boundary condition. The initial local geometric imperfection distribution pattern of each stub column FE model was assumed to be of the lowest elastic local buckling mode shape [18,31]. Five imperfection amplitudes, including the measured values and four fractions of the wall thicknesses $(t / 100, t / 50, t / 25$ and $t / 10$ ), were utilised to factor the initial local geometric imperfection distribution shape, for the purpose of assessing the sensitivity of the press-braked S960 UHSS angle and channel section stub column FE models to the imperfection amplitudes.

\subsection{Validation of FE models}

Upon development of the press-braked S960 UHSS angle and channel section stub column FE models, static Riks analysis [28], which considers both the geometric and material nonlinearities, was performed to acquire the numerical ultimate loads, load-axial end shortening responses and failure modes, which were then compared with the experimentally observed results, enabling the accuracy of the developed angle and channel section stub column FE models to be assessed. The ratios of the numerical to test ultimate loads $N_{u, F E} / N_{u \text {,test }}$ for press-braked S960 UHSS angle and channel section stub columns are presented in Tables 7 and 8. It was generally found that all the examined initial local geometric imperfection amplitudes yield precise predictions of the experimental failure loads, while the most accurate predictions were attained when the initial local geometric imperfection amplitude of $t / 10$ was adopted. The FE models were also found to be capable of simulating the experimental loadaxial end shortening histories, examples of which are displayed in Fig. 11. Excellent agreement was also obtained for the deformed failure modes; typical examples are depicted in Fig. 12(a) and Fig. 12(b) for angle section stub column specimen A 140×6 and channel section stub column specimen C $120 \times 90 \times 6$, respectively. In sum, it may be concluded that the developed FE models can accurately and reliably simulate the experimental structural responses of the S960 UHSS angle and channel section stub column specimens.

\subsection{Parametric studies}

Upon validation of the FE models, parametric studies were carried out, aimed at generating additional numerical results over a wide variety of cross-section sizes. Table 9 summarises the cross-section geometric sizes of all the modelled S960 UHSS angle and channel section stub columns. The specimen lengths were selected to be $2.5 B$ and $1.25\left(B_{w}+B_{f}\right)$ for the angle and channel section stub column FE models, respectively. The modelling procedures and techniques relevant to the development of angle and channel section stub column FE models, as presented in Section 3.2, were also employed in the present parametric studies, but with some supplementary information highlighted herein: (i) the flat and corner stress-strain curves measured from angle section A $60 \times 6$ were incorporated into the respective parts of angle section FE models, whilst the material responses obtained from channel section $\mathrm{C} 120 \times 90 \times 6$ were assigned to the channel section FE models, and (ii) the initial local imperfection amplitudes were taken as $1 / 10$ of the wall thicknesses of the modelled cross-sections. Overall, a total of 116 and 128 parametric study results were respectively generated for press-braked S960 UHSS angle and channel section stub columns. 


\section{Evaluation of current international design standards}

\subsection{General}

The current European code EN 1993-1-12 [5] for high strength steels is an extension of EN 1993-1-1 [32] for normal strength steels and only covers the design of hot-rolled and welded steel structural members with material grades up to S700, whilst the North American specification AISI S100 [6] and the Australian/New Zealand standard AS/NZS 4600 [7], though established specifically for cold-formed steel structural members, are only applicable to steels with grades up to S690. Therefore, none of the existing codes can be directly used for the design of press-braked S960 UHSS angle and channel section structural members. In the present Section 4, the applicability of the codified design rules for S690 HSS angle and channel section stub columns was evaluated for their S960 UHSS counterparts, followed by the development of revised codified design rules.

\subsection{EN 1993-1-12 (EC3)}

\subsubsection{General}

The current EN 1993-1-12 [5] adopts the cross-section classification approach and effective width formulations for the treatment of stub columns failing by local buckling. Classification of a cross-section is made according to the class of its most slender constituent plate element, whilst each constituent plate element within the cross-section is categorised through comparing its flat width-to-thickness ratio $c / t \varepsilon$ against the prescribed slenderness limits, where $\varepsilon=\left(235 / f_{y}\right)^{0.5}$ is a material coefficient, and $c$ is taken as the flat element width excluding the corner radius for webs and flanges of channel sections but given as the outer element width for legs of angle sections. Cross-sections classified as Class 1,2 and 3 can achieve the yield loads under compression $A f_{\mathrm{y}}$, while their Class 4 counterparts fail before the material yield stress is acquired, limiting the cross-section compression capacities to the effective compression capacities $A_{\text {eff } f} y$, where $A_{\text {eff }}$ is the effective area of the cross-section, given as the sum of the full areas of the corners and effective areas of the flat portions. The effective area of each flat plate element of the cross-section is determined as the product of the wall thickness and the effective plate element width $c_{\text {eff. }}$. For slender outstand and internal plate elements in pure compression (i.e. subjected to uniform compressive stress), the effective plate element widths $c_{\text {eff }}$ are determined from Eqs (1) and (2) [33], respectively, where $\bar{\lambda}_{p}$ is the local slenderness of the examined plate element, as derived from Eq. (3), in which $f_{c r}$ is the elastic local buckling stress of the plate element. In the following Section 4.2.2, evaluation on the suitability of the codified slenderness limits to press-braked S960 UHSS angle and channel sections was firstly conducted, followed by assessment of the EC3 design cross-section compression resistances in Section 4.2.3, whilst revised EC3 design rules were proposed in Section 4.2.4.

$$
\begin{gathered}
c_{\text {eff }}=\left(\frac{1}{\bar{\lambda}_{p}}-\frac{0.22}{\bar{\lambda}_{p}^{2}}\right) c \leq c \text { for } \bar{\lambda}_{p} \geq 0.673 \\
c_{\text {eff }}=\left(\frac{1}{\bar{\lambda}_{p}}-\frac{0.188}{\bar{\lambda}_{p}{ }^{2}}\right) c \leq c \text { for } \bar{\lambda}_{p} \geq 0.748
\end{gathered}
$$




$$
\bar{\lambda}_{p}=\sqrt{\frac{f_{y}}{f_{c r}}}
$$

\subsubsection{Evaluation on current EC3 Class 3 slenderness limits}

For all the examined press-braked S960 UHSS channel sections with cross-section aspect ratios falling within the practically used range from 1.0 to 3.0 [34], the outstand flanges are always more critical and slender than the internal webs, i.e. the overall class of a channel section is governed by its flange class. Therefore, only the Class 3 slenderness limit for outstand plate elements in compression was evaluated herein. The test and FE ultimate loads of press-braked S960 UHSS channel section stub columns, normalised by the respective cross-section yield loads $A f_{y}$, are plotted against the $c / t \varepsilon$ ratios of the flanges of the examined channel sections in Fig. 13, together with the EC3 Class 3 slenderness limit for outstand plate elements in compression $(c / t \varepsilon=14)$. The results of the graphic evaluation indicated that the current EC3 Class 3 slenderness limit for outstand plate elements in compression lead to unsafe classification of the flanges of press-braked S960 UHSS channel section stub columns.

For equal-leg angle section stub columns subjected to compression, non-slender (Class 1, Class 2 and Class 3) cross-sections are defined as those with the leg width-to-thickness ratios less than or equal to $11.5 \varepsilon$, as specified in the current EN 1993-1-1 [32] and EN 1993-1-12 [5]. It is worth noting that full element widths are employed in the classification of angle legs, in comparison with the classification of channel flanges, which is based on the flat element width excluding the corner radius; moreover, the current Eurocodes employ different Class 3 slenderness limits for outstand flanges of channel sections $(c / t \varepsilon \leq 14)$ and outstand legs of angle sections $(c / t \varepsilon \leq 11.5)$. The suitability of the EC3 slenderness limit for angle legs in compression was evaluated, based on the press-braked S960 UHSS channel section stub column test and numerical data, with the graphic evaluation results depicted in Fig. 14, revealing that the current EC3 slenderness limit for angle legs in compression is safe and accurate when used for the classification of the legs of S960 UHSS equal-leg angle section stub columns.

\subsubsection{Comparisons of experimental and numerical results with EC3 resistance predictions}

In this section, the unfactored EC3 design cross-section compression resistances (i.e. yield loads for non-slender sections and effective compression capacities for slender sections) were compared against the ultimate loads of press-braked S960 UHSS angle and channel section stub columns derived from the structural testing and finite element modelling. The mean test and FE to EC3 predicted ultimate load ratios $N_{u} / N_{E C 3}$, as presented in Table 10 , are respectively equal to 1.14 and 1.20 for non-slender and slender S960 UHSS angle section stub columns, with the coefficients of variation (COVs) of 0.016 and 0.066 ; this indicates that the design cross-section compression resistance predictions are safe-sided but still relatively accurate and consistent, as also evident in Fig. 15, where the test (and FE) to EC3 predicted failure load ratios $N_{u} / N_{E C 3}$ are plotted against the corresponding leg width-to-thickness ratios $c / t$. Regarding press-braked S960 UHSS non-slender and slender channel section stub columns, the average test and FE to EC3 predicted failure load ratios are 1.03 and 0.99 , with the COVs of 0.048 and 0.034, respectively, as reported in Table 11, revealing that EN 1993-1-12 [5] yields an overall high level of design accuracy and consistency. However, it is worth noting that many of the 
EC3 design cross-section compression resistances lie on the unsafe side, as evident in Fig. 16, where graphical comparisons of the test and FE failure loads of S960 UHSS channel section stub columns with the EC3 design cross-section compression resistances are presented. The unsafe design cross-section compression resistance predictions stem essentially from the overoptimistic classification of press-braked S960 UHSS channel sections.

\subsubsection{Revised EC3 design rules}

The current EC3 Class 3 slenderness limit for outstand plate elements in compression was found to result in unsafe classification of the flanges of press-braked S960 UHSS channel section stub columns. It may be primarily due to the fact that the concept of flat element width (used in the classification framework) was originated from mill steel hot-rolled and coldformed sections, where the corner radii are similar to the plate thicknesses, and thus may not be suitable for S960 UHSS press-braked sections, where the corner radii are significantly larger than the plate thicknesses in order to avoid material fracture of S960 ultra-high strength steel during the press-braking process. Therefore, a revised classification framework for the outstand flanges of press-braked S960 UHSS channel sections was proposed herein based on the use of full element widths (instead of flat element widths), i.e. in line with that for angle legs. Note that the use of centreline width $b_{p}$, given as the width measured from the midpoints of the adjacent corner elements according to EN 1993-1-3 [36], was also attempted in the preliminary study, but generally shown to result in some unsafe cross-section classification results and cross-section compression resistance predictions. The experimental and numerical ultimate loads of press-braked S960 UHSS channel section stub columns, normalised by the crosssection yield loads, are plotted against the full flange width-to-thickness ratios of the examined channel sections in Fig. 17, together with the EC3 Class 3 slenderness limit for outstand plate elements in compression ( $c / t \varepsilon=14$ ), where $c$ is now taken as the full flange width $B_{f}$. The graphic evaluation results indicated that the proposed classification framework (carried out based on the full element widths) led to safe and accurate classification of the outstand flanges of pressbraked S960 UHSS channel section stub columns, based on which the EC3 design cross-section compression resistances were then calculated; note that for Class 4 (slender) channel sections, the effective elements widths were now determined based on the full element widths, i.e. $c$ is given as the full flange width $B_{f}$ in Eqs (1) and (2). Quantitative and graphic evaluations of the revised EC3 design cross-section compression resistances $\left(N_{E C 3^{*}}\right)$ were presented in Table 11 and Fig. 16, indicating that the revised EC3 design cross-section compression resistances are safe, accurate and consistent when compared with the test and numerical failure loads. It is therefore recommended that both the cross-section classification and effective width calculations be carried out based on the full element widths for press-braked S960 UHSS channel sections.

\subsection{AISI S100 and AS/NZS 4600}

\subsubsection{Comparisons of test and numerical results with AISI (or AS/NZS) resistance predictions}

The North American Specification AISI S100 [6] and Australian/New Zealand Standard AS/NZS 4600 [7] adopt the same approach for the design of compression members. With regards to concentrically loaded angle section columns (regardless of member lengths), both of the two standards specify that they should always be designed as eccentrically loaded beamcolumns (with the eccentricities with respect to the cross-section minor principal axes equal to $L / 1000$ ) according to the interaction formula given by Eq. (4), where $N_{a n}$ is the design compressive strength, $N_{n l}$ is the nominal axial strength and $M_{n l}$ is the flexure strength, 
respectively taken as the elastic and effective moment resistances for non-slender and slender sections. For concentrically loaded channel section columns (regardless of member lengths), the design compressive strengths are taken as the nominal axial strengths $N_{n l}$. The nominal axial strength of an angle or channel section column $N_{n l}$ was determined as the product of the design failure stress $f_{n}$ and the effective cross-section area at the design failure stress $A_{\text {eff, as }}$ given by Eq. (5). The design failure stress takes into account the interaction of global buckling with local buckling and can be calculated from Eq. (6), where $\lambda_{c}=\left(f_{y} / f_{c r e}\right)^{0.5}$, in which $f_{\text {cre }}$ is the least of the member elastic flexural, torsional and flexural-torsional buckling stresses; note that calculated design failure stresses $f_{n}$ approximates to the material yield stresses $f_{y}$ for channel section stub columns and non-slender angle section stub columns, but can be much less than the material yield stress $f_{y}$ for slender angle section stub columns. The effective cross-section area at the design failure stress is determined based on the effective width formula given by Eq. (7), in which $c$ is taken as the flat element width excluding the corner radius and $\lambda=\left(f_{n} / f_{c r}\right)^{0.5}$; note that AISI S100 [6] and AS/NZS 4600 [7] use the same effective width formula for both the outstand and internal plate elements in compression.

$$
\begin{gathered}
\frac{N_{a n}}{N_{n l}}+\frac{N_{a n} L / 1000}{M_{n l}}=1 \\
N_{n l}=f_{n} A_{e f f} \\
f_{n}= \begin{cases}\left(0.658^{\lambda_{c}{ }^{2}}\right) f_{y} & \text { for } \lambda_{c} \leq 1.5 \\
\left(\frac{0.877}{\lambda_{c}^{2}}\right) f_{y} & \text { for } \lambda_{c}>1.5\end{cases} \\
c_{\text {eff }}=\left(\frac{1}{\lambda}-\frac{0.22}{\lambda^{2}}\right) c \leq c
\end{gathered}
$$

Quantitative and graphical comparisons of the predicted cross-section compressive strengths by AISI S100 $\left(N_{\text {AISI }}\right)$ and AS/NZS $4600\left(N_{A S / N Z S}\right)$ with the test and numerical failure loads of press-braked S960 UHSS angle and channel section stub columns were performed and presented in Tables 10-11 and Figs 18-19, respectively. Similarly to EN 1993-1-12 [5], AISI S100 [6] and AS/NZS 4600 [7] yield overall accurate and consistent design cross-section compressive strengths for press-braked S960 UHSS channel section stub columns, but many of the predicted cross-section compressive strengths lie on the unsafe side. The predictions of cross-section compressive strengths were generally found to be safe, accurate and consistent (when compared against the corresponding test and numerical failure loads) for press-braked S960 UHSS non-slender angle section stub columns, but excessively conservative and scattered for their slender counterparts.

\subsubsection{Revised AISI S100 and AS/NZS 4600 design rules}

Revised AISI and AS/NZS design rules were proposed in this section, aimed at leading to more accurate and consistent but still safe-sided cross-section compressive strength predictions for press-braked S960 UHSS angle and channel section stub columns. Specifically, it was proposed that (i) the calculation of plate element slenderness $\lambda$ and the application of effective width formulation are both based on the full width of the plate element instead of the flat element width and (ii) the design failure stress is taken as the material yield stress for slender angle section stub columns without explicitly taking into account torsional buckling and flexural-torsional buckling [35]. On this basis, the AISI (or AS/NZS) design cross-section compressive strengths for press-braked S960 UHSS angle and channel section stub columns 
$\left(N_{A I S I^{*}}\right.$ or $\left.N_{A S / N Z S^{*}}\right)$ were determined, and then compared against the experimentally and numerically obtained failure loads. The results of the comparisons, as reported in Table 10 and Figs. 18 and 19, revealed that the revised AISI and AS/NZS design rules lead to safe-sided but still accurate and consistent cross-section compressive strength predictions for press-braked S960 UHSS channel section stub columns and non-slender angle section stub columns, and also yield notably improved design cross-section compressive strengths for press-braked S960 UHSS slender angle section stub columns.

\section{Conclusions}

A systematic experimental and numerical study has been performed to examine the crosssection compressive behaviour and resistances of press-braked S960 UHSS angle and channel section stub columns, and presented in this paper. The experimental study included material tensile flat and corner coupon tests, initial local geometric imperfection measurements and eighteen stub column tests, whilst the numerical investigation comprised a simulation study to replicate the test structural responses of the S960 UHSS angle and channel section stub column specimens and a parametric study to derive an additional numerical data bank over a wide variety of cross-section dimensions. The obtained test and numerical data was adopted to assess the suitability of the codified provisions, given in EN 1993-1-12 [5], AISI S100 [6] and AS/NZS 4600 [7], to the design of S960 UHSS angle and channel section stub columns. The assessment results generally revealed that (i) the European code EN 1993-1-12 [5] yields precise and consistent design cross-section compression resistances, on average, but with many unsafe predicted resistances for S960 UHSS channel section stub columns, and (ii) the North American specification AISI S100 [6] and Australian/New Zealand standard AS/NZS 4600 [7] not only often result in overestimated predictions of cross-section compression resistances for S960 UHSS channel section stub columns, but also lead to overly conservative design crosssection compression resistances for S960 UHSS slender angle section stub columns. Revised EC3 design rules were then proposed through the use of full element widths in the cross-section classification framework and effective width approach, while modifications to the AISI and AS/NZS design provisions were also made by utilising full element widths in the application of effective width formulations and taking the material yield stress as the design failure stress for slender angle section stub columns, all of which were shown to yield substantially improved (safe, accurate and consistent) design cross-section compression resistance predictions over the original codified design rules.

\section{Acknowledgements}

The authors thank SSAB Swedish Steel Pte Ltd, Singapore and Vision One Pte Ltd for their assistances in fabricating press-braked S960 UHSS equal-leg angle sections and plain channel sections, and are also grateful to Mr Jun Wei Toh and Mr Shao Quan Ong for their help in the concentrically load stub column tests.

\section{References}

[1] Li D, Huang Z, Uy B, Thai H T, Hou C. Slenderness limits for fabricated S960 ultra-highstrength steel and composite columns. Journal of Constructional Steel Research, 2019;159:109121. 
[2] Sun Y, Liang Y, Zhao O. Testing, numerical modelling and design of S690 high strength steel welded I-section stub columns. Journal of Constructional Steel Research, 2019;159:521533.

[3] Shi G, Zhou W, Lin C. Experimental investigation on the local buckling behavior of 960 MPa high strength steel welded section stub columns. Advances in Structural Engineering, 2015;18(3):423-437.

[4] Ma J L, Chan T M, Young B. Experimental investigation on stub-column behavior of coldformed high-strength steel tubular sections. Journal of Structural Engineering (ASCE), 2015;142(5):04015174.

[5] EN 1993-1-12. Eurocode 3: Design of steel structures - Part 1-12: Additional rules for the extension of EN 1993 up to steel grades S 700. Brussels (Belgium): CEN; 2007.

[6] AISI S100. North American specification for the design of cold-formed steel structural members. American Iron and Steel Institute; 2016.

[7] AS/NZS 4600. Cold-formed steel structures. Australian/New Zealand Standard, Sydney: AS/NZS 4600:2018; 2018.

[8] SSAB. Bending of high strength steel-Strenx, Hardox and Docol. https://www.ssab.com/products/brands/strenx/products/strenx-960?accordion=downloads

[9] EN 10025-6. Hot rolled products of structural steels. Technical delivery conditions for flat products of high yield strength structural steels in the quenched and tempered condition. Brussels: European Committee for Standardization (CEN); 2019.

[10] Ziemian RD. Guide to stability design criteria for metal structures. 6th ed. John Wiley \& Sons; 2010.

[11] Quach WM, Teng JG, Chung KF. Effect of the manufacturing process on the behaviour of press-braked thin-walled steel columns. Engineering Structures, 2010;32:3501-15.

[12] American Society for Testing and Materials (ASTM). Standard test methods for tension testing of metallic materials. E8/E8M-15a, West Conshohocken, PA., USA: ASTM International; 2015.

[13] Huang Y, Young B. The art of coupon tests. Journal of Constructional Steel Research, 2014;96:159-75.

[14] Wang F, Young B, Gardner L. Compressive testing and numerical modelling of concretefilled double skin CHS with austenitic stainless steel outer tubes. Thin-Walled Structures, 2019; 141:345-359.

[15] Wang F, Young B, Gardner L. Experimental Study of Square and Rectangular CFDST Sections with Stainless Steel Outer Tubes under Axial Compression. Journal of Structural Engineering. 2019;145(11):04019139.

[16] Zhang L, Tan KH, Zhao O. Experimental and numerical studies of fixed-ended coldformed stainless steel equal-leg angle section columns. Engineering Structures. 2019;184:13444.

[17] Fang H, Chan T M, Young B. Material properties and residual stresses of octagonal high strength steel hollow sections. Journal of Constructional Steel Research, 2018;148:479-490.

[18] Zhang L, Wang F, Liang Y, Zhao O. Press-braked S690 high strength steel equal-leg angle and plain channel section stub columns: Testing, numerical simulation and design, Engineering Structures, 2019;201:109764.

[19] Wang F, Zhao O, Young B. Flexural behaviour and strengths of press-braked S960 ultrahigh strength steel channel section beams. Engineering Structures. 2019;200:109735.

[20] Popovic D, Hancock GJ, Rasmussen KJR. Axial Compression Tests of Cold-Formed Angles. Journal of Structural Engineering. 1999;125:515-23.

[21] Li H-T, Young B. Design of cold-formed high strength steel tubular sections undergoing web crippling. Thin-Walled Structures. 2018;133:192-205. 
[22] Jiao H, Zhao X L. Imperfection, residual stress and yield slenderness limit of very high strength (VHS) circular steel tubes. Journal of Constructional Steel Research, 2003, 59(2): 233249.

[23] Schafer B, Peköz T. Computational modeling of cold-formed steel: characterizing geometric imperfections and residual stresses. Journal of constructional steel research. 1998;47:193-210.

[24] Sun Y, Zhao O. Material response and local stability of high-chromium stainless steel welded I-sections. Engineering Structures, 2019;178:212-26.

[25] Pandey M, Young B. Compression capacities of cold-formed high strength steel tubular T-joints. Journal of Constructional Steel Research. 2019;162.

[26] Centre for Advanced Structural Engineering. Compression tests of stainless steel tubular columns. Investigation report S770. University of Sydney; 1990.

[27] Gardner L, Nethercot D A. Experiments on stainless steel hollow sections-Part 1: Material and cross-sectional behaviour. Journal of Constructional Steel Research, 2004, 60(9): 1291-1318.

[28] ABAQUS. ABAQUS/standard user's manual. Version 6.17. Dassault Systemes Simulia Corp. USA; 2017.

[29] Wang J, Gardner L. Flexural Buckling of Hot-Finished High-Strength Steel SHS and RHS Columns. Journal of Structural Engineering. 2017;143.

[30] Ma J L, Chan T M, Young B. Material properties and residual stresses of cold-formed high strength steel hollow sections. Journal of Constructional Steel Research, 2015;109: 152165.

[31] Zhang L, Tan KH, Zhao O. Local stability of press-braked stainless steel angle and channel sections: Testing, numerical modelling and design analysis. Engineering Structures. 2020;203:109869.

[32] EN 1993-1-1. Eurocode 3: Design of steel structures - Part 1-1: General rules and rules for buildings. Brussels (Belgium): CEN; 2005.

[33] EN 1993-1-5. Eurocode 3: Design of steel structures - Part 1-5: Plated structural elements. Brussels: European Committee for Standardization (CEN); 2015.

[34] SSAB S960 channel section online brochure. https://www.ssab.com/products/steelcategories/open-sections/products/ssab-cold-formed-c-section

[35] Young B. Tests and Design of Fixed-Ended Cold-Formed Steel Plain Angle Columns. Journal of Structural Engineering. 2004;130:1931-40.

[36] EN 1993-1-3. Eurocode 3: Design of steel structures -Part 1-3: General rules Supplementary rules for cold-formed members and sheeting. Brussels (Belgium): CEN; 2006. 


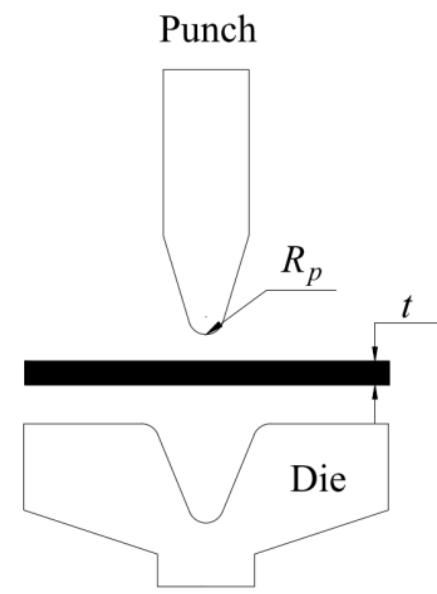

(a) Press brake setup

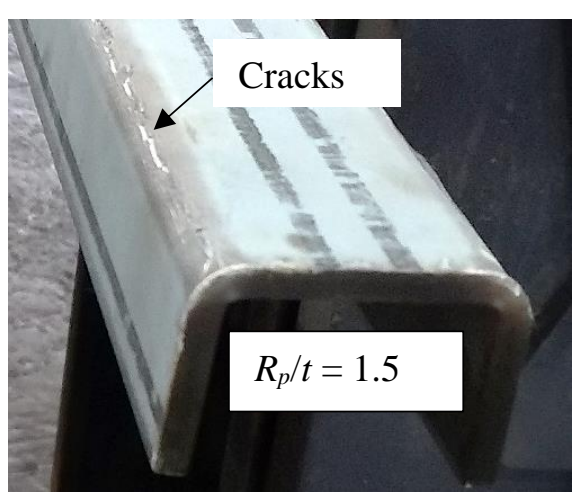

(b) Specimen press-braked without following the bend radius requirement

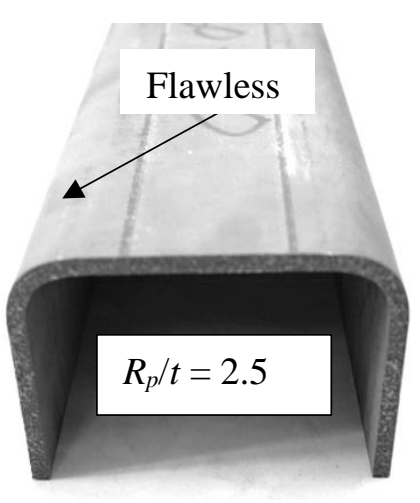

(c) Specimen press-braked following the bend radius requirement

Fig. 1. Press brake of S960 UHSS specimens.
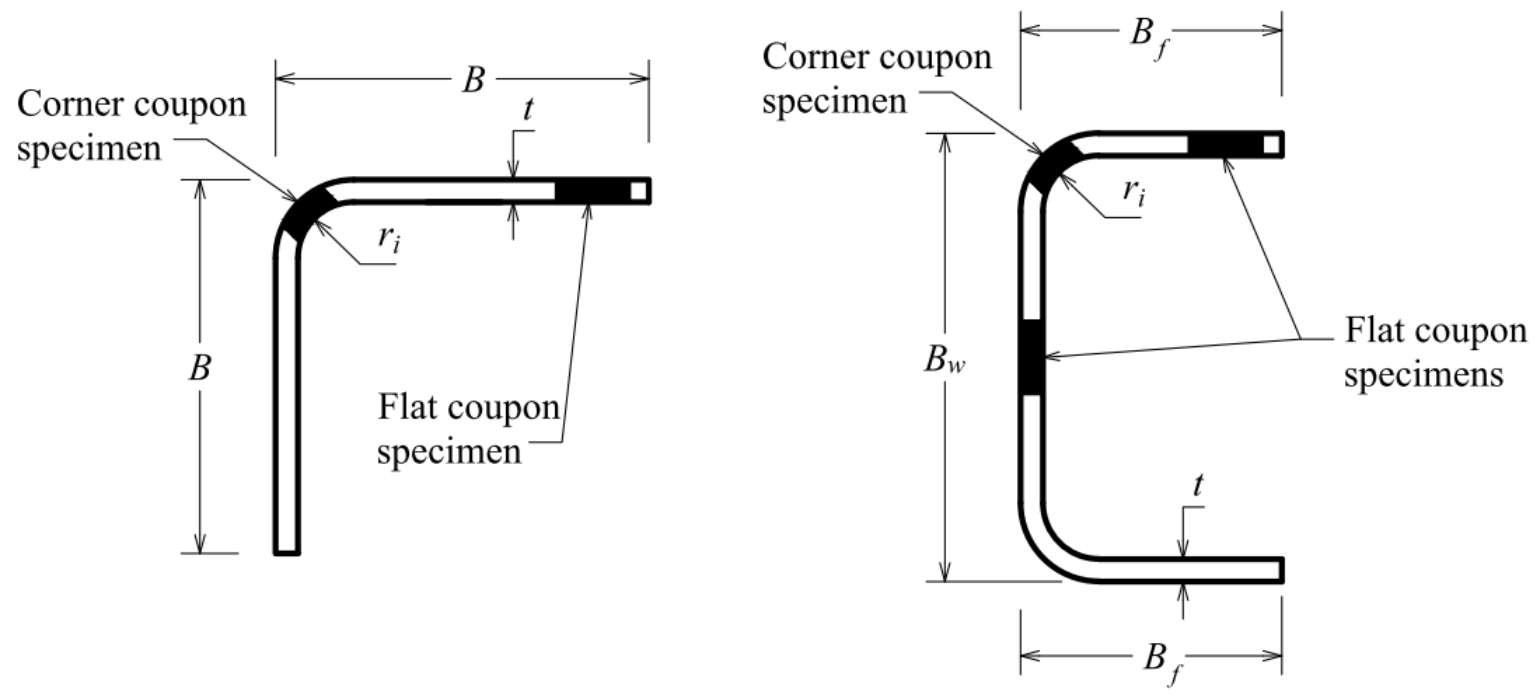

(a) Angle section

(b) Channel section

Fig. 2. Definition of symbols and locations of tensile coupons within cross-sections. 


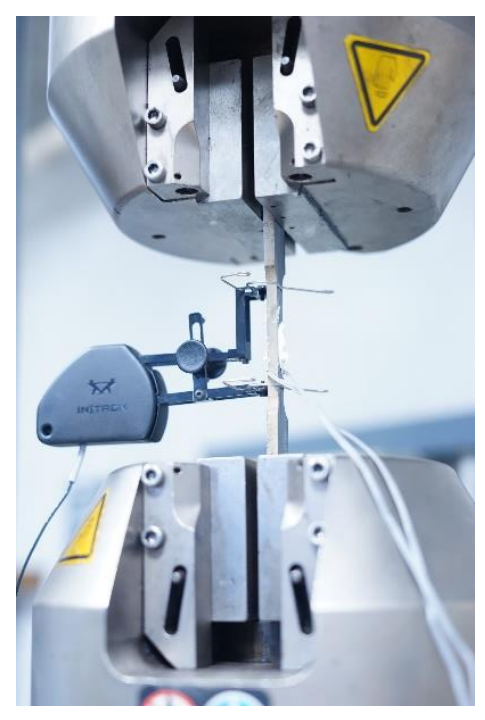

(a) Flat coupon test setup

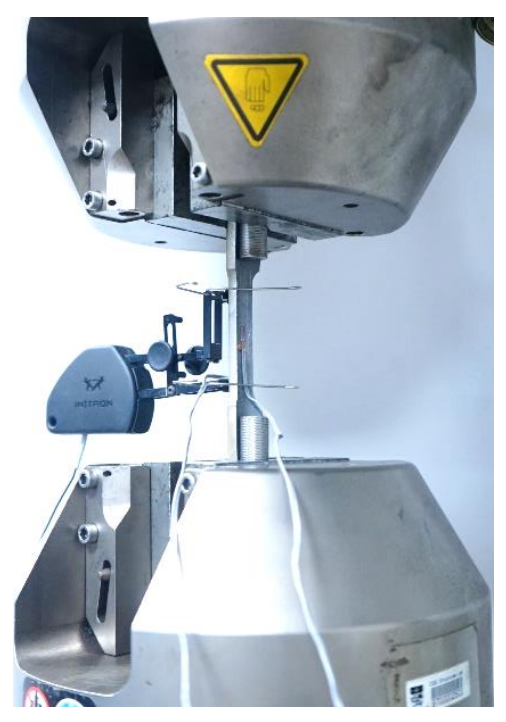

(b) Corner coupon test setup

Fig. 3. Tensile coupon test setups.

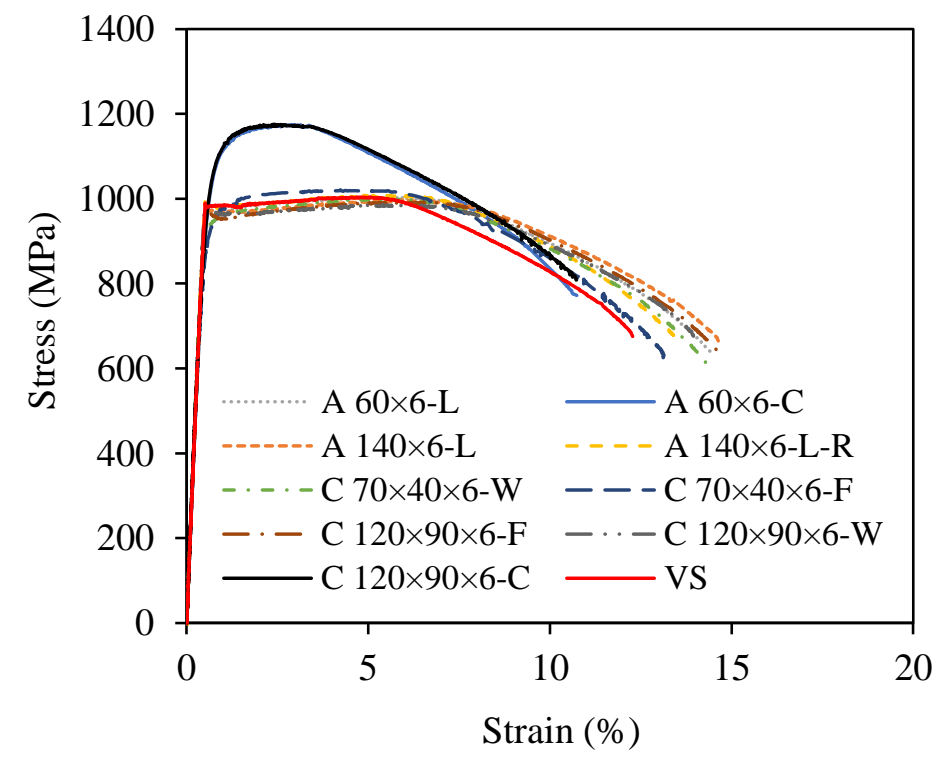

Fig. 4. Stress-strain curves obtained from tensile coupon tests. 


\section{CNC ROUTER}

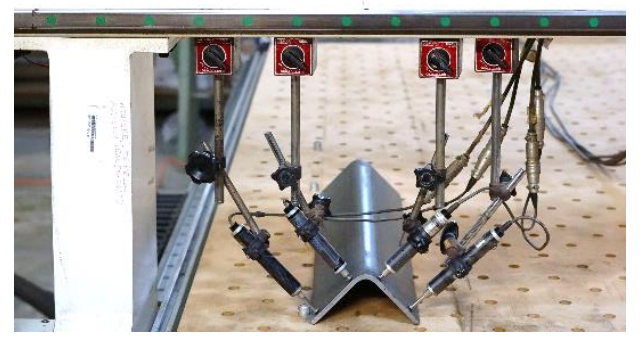

(a) Angle section stub column specimen A $60 \times 6$

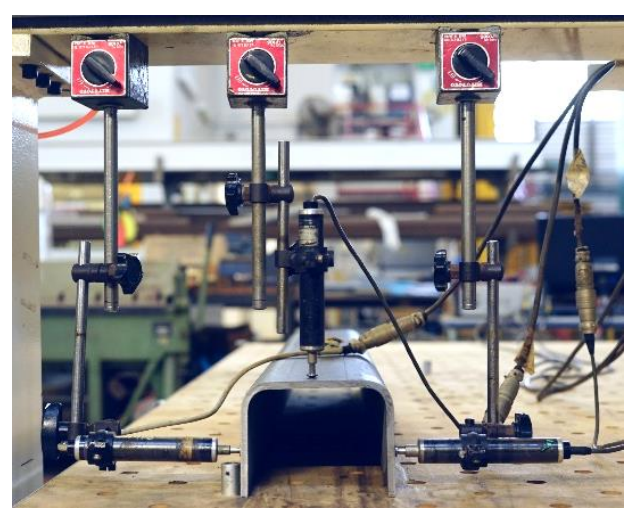

(b) Channel section stub column specimen C $120 \times 90 \times 6$

Fig. 5. Initial local geometric imperfection measurement setups for angle and channel section stub column specimens.

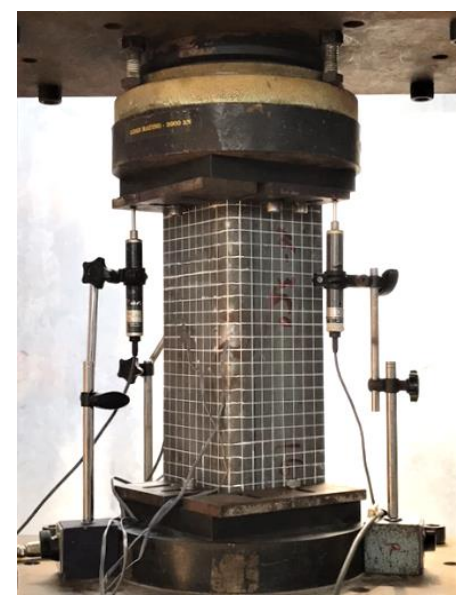

(a) Front view
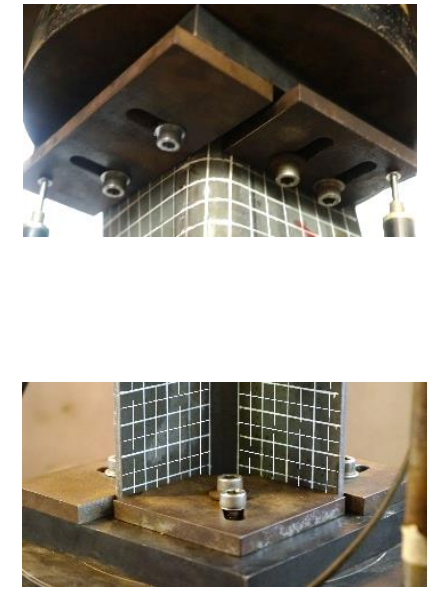

(b) Stiffening device

Fig. 6. Angle section stub column test setup.

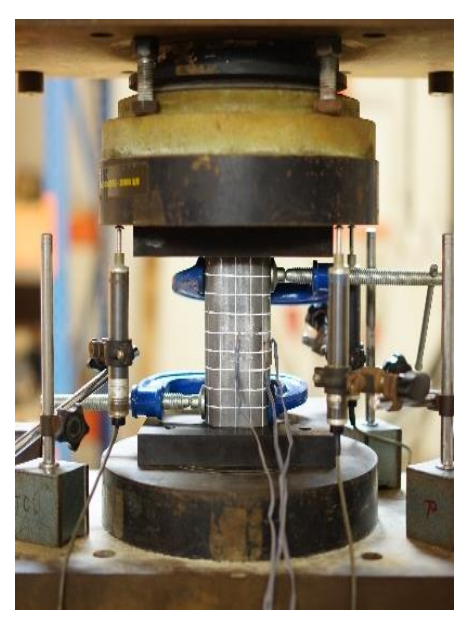

(a) Front view

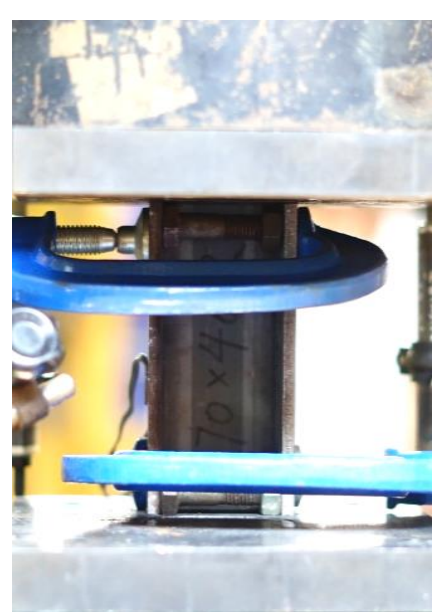

(b) Stiffening device

Fig. 7. Channel section stub column test setup. 


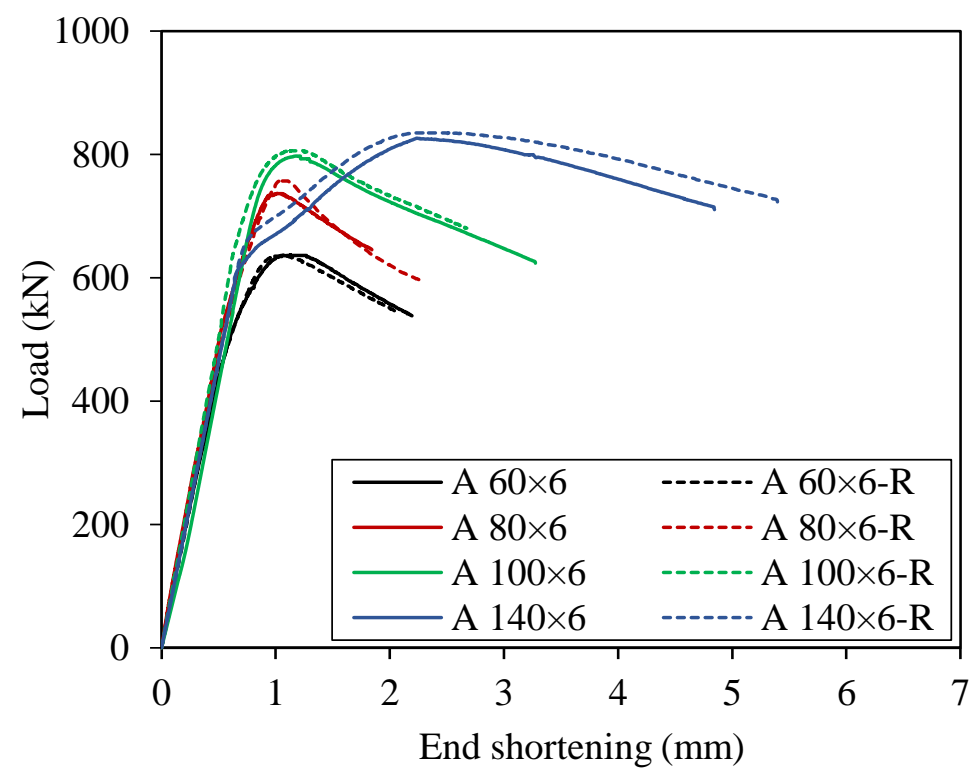

Fig. 8. Load-end shortening curves of the tested press-braked S960 UHSS angle section stub columns.

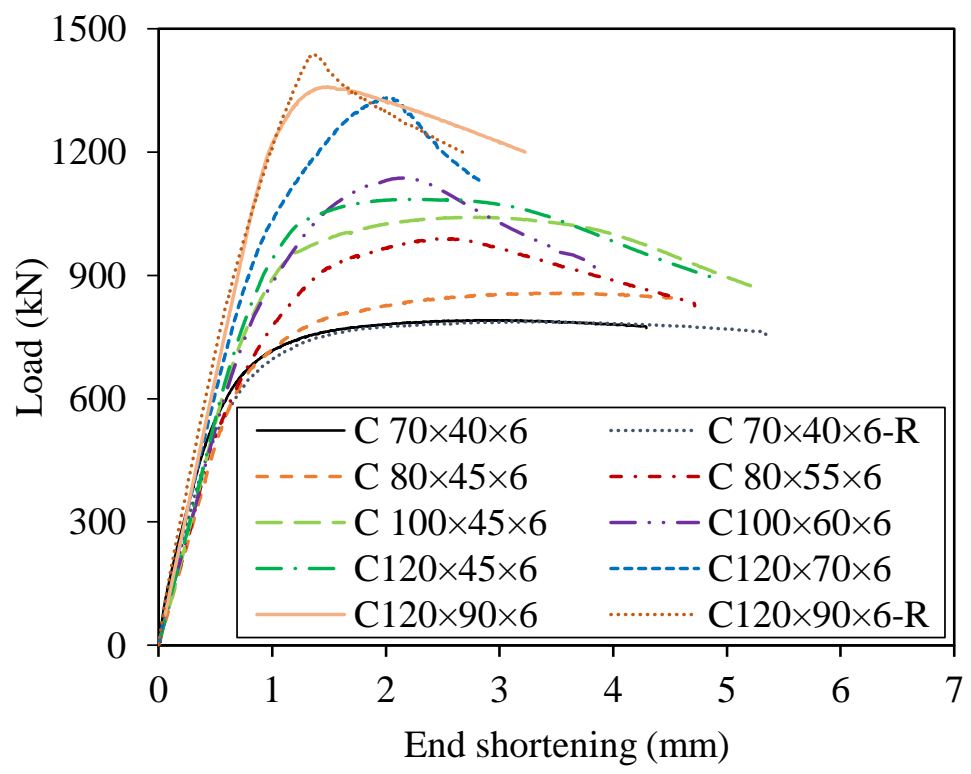

Fig. 9. Load-end shortening curves of the tested press-braked S960 UHSS channel section stub columns. 


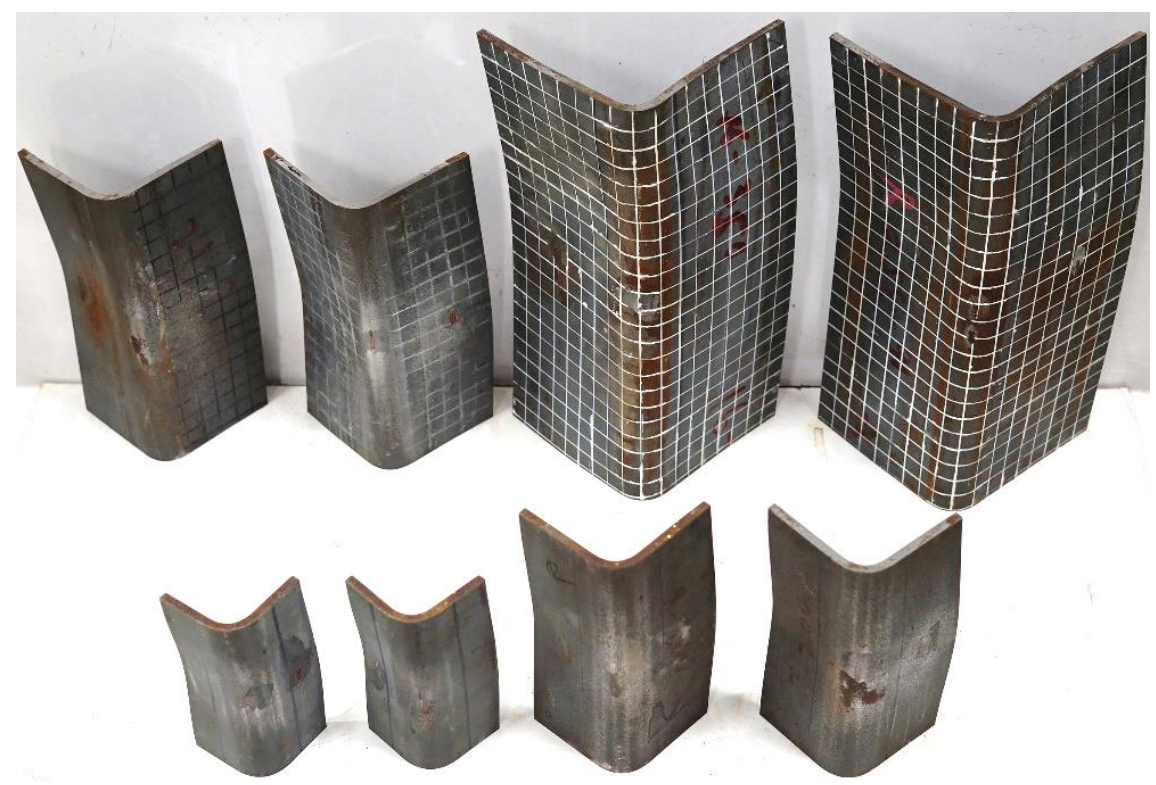

(a) Angle section stub column specimens.
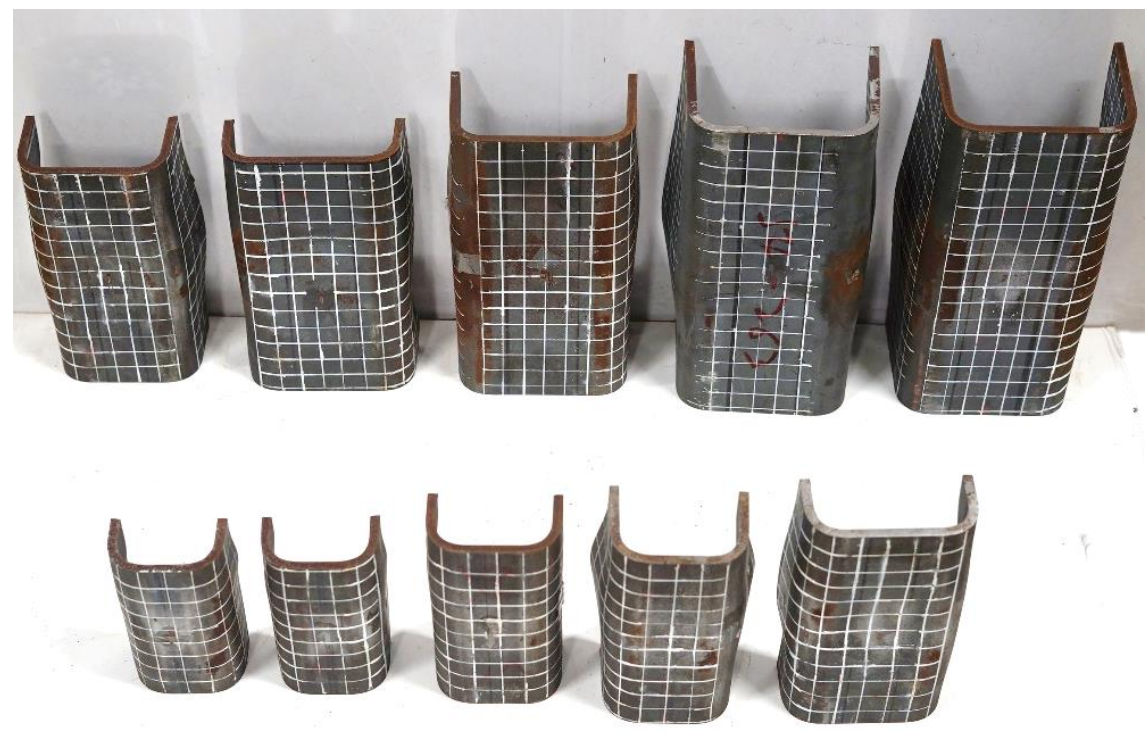

(b) Channel section stub column specimens.

Fig. 10. Experimental failure modes of press-braked S960 UHSS stub column specimens. 


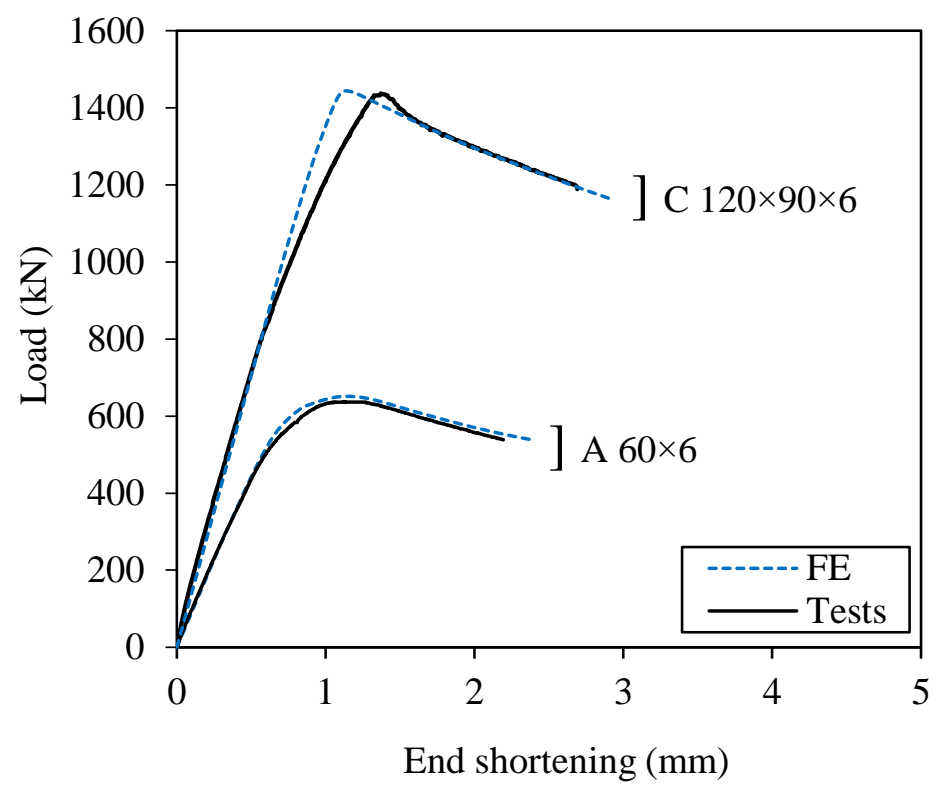

Fig. 11. Comparison of test and FE load-end shortening curves for typical press-braked S960 UHSS stub column specimens.
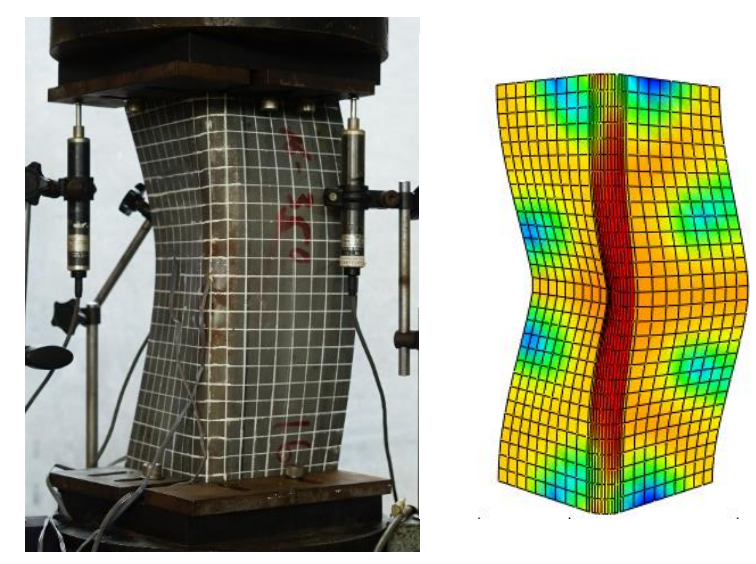

(a) Angle section stub column specimen A 140×6.
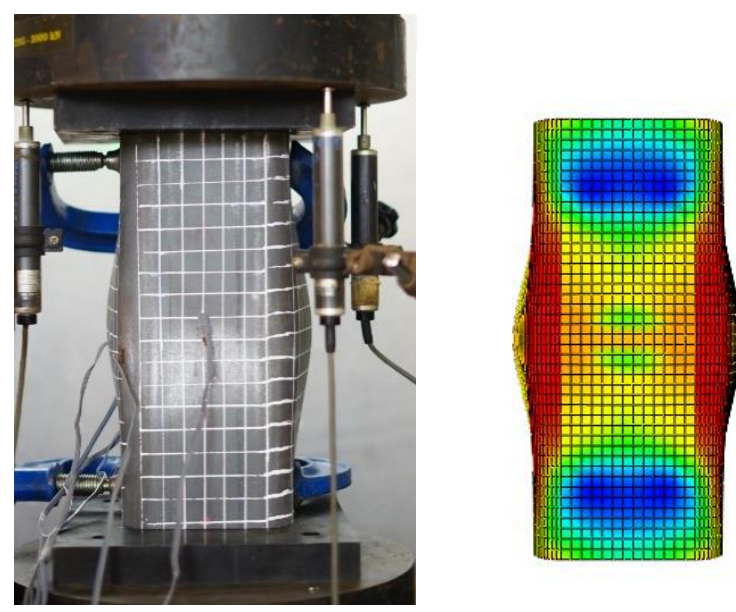

(b) Channel section stub column specimen C $120 \times 90 \times 6$.

Fig. 12. Test and FE failure modes for typical press-braked S960 UHSS stub column specimens. 


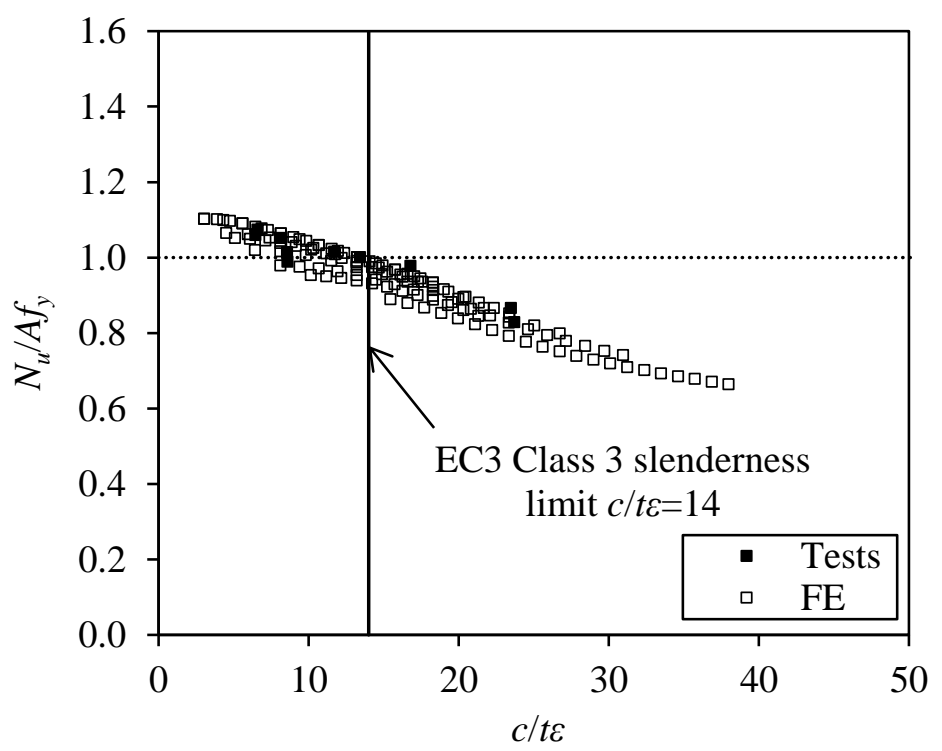

Fig. 13. Assessment of EC3 Class 3 slenderness limit for outstand flanges of channel sections in compression.

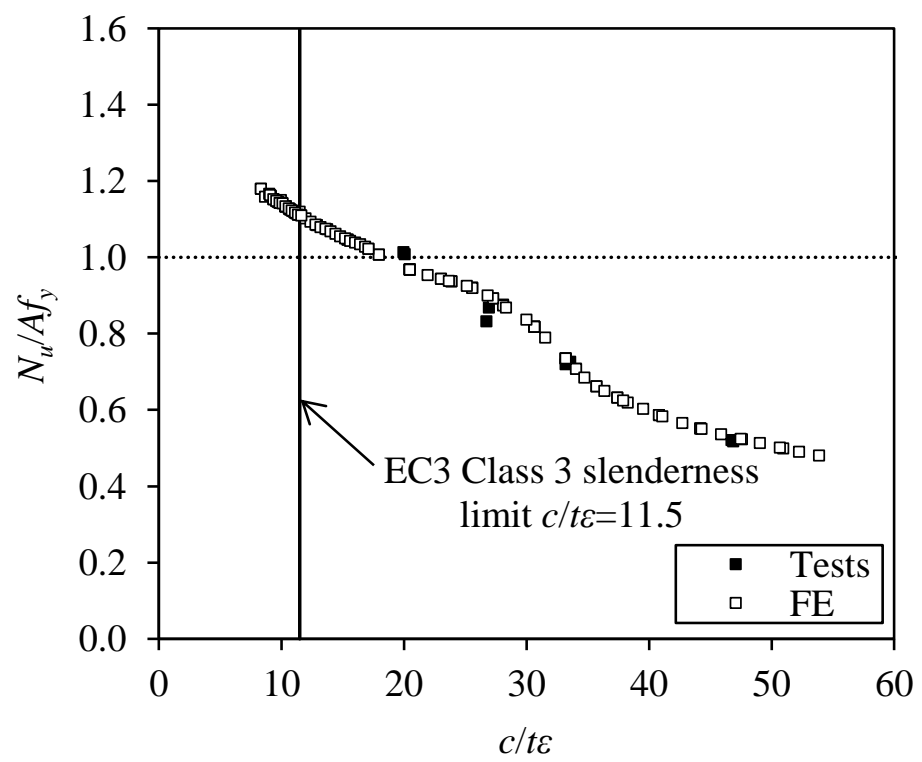

Fig. 14. Assessment of EC3 Class 3 slenderness limit for outstand legs of equal-leg angle sections in compression. 


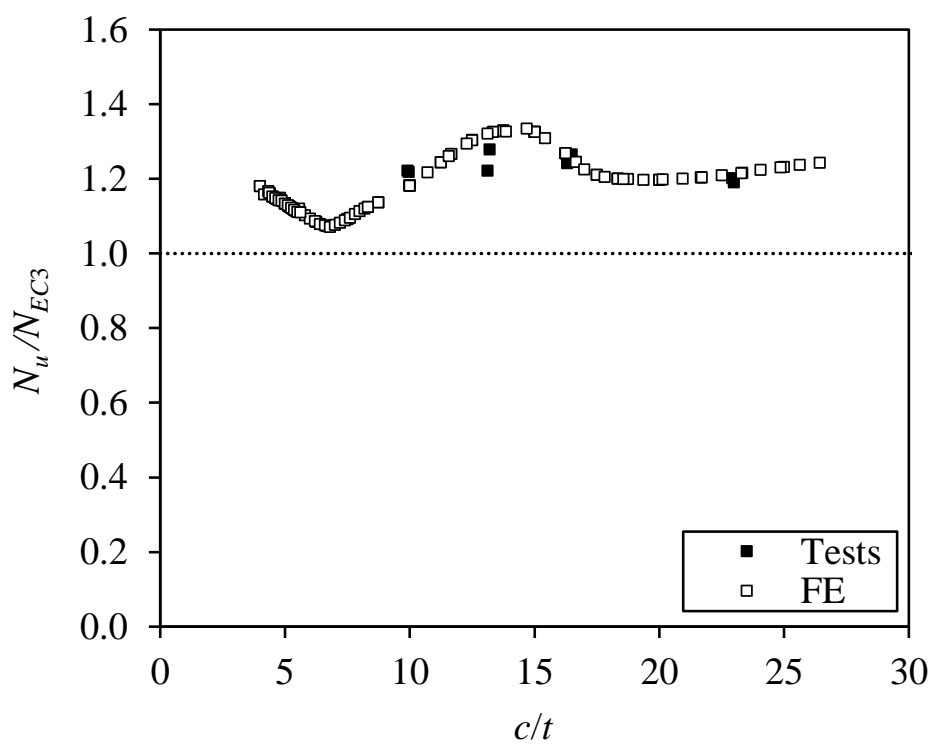

Fig. 15. Comparisons of press-braked S960 UHSS angle section stub column test and FE failure loads with EC3 resistance predictions.

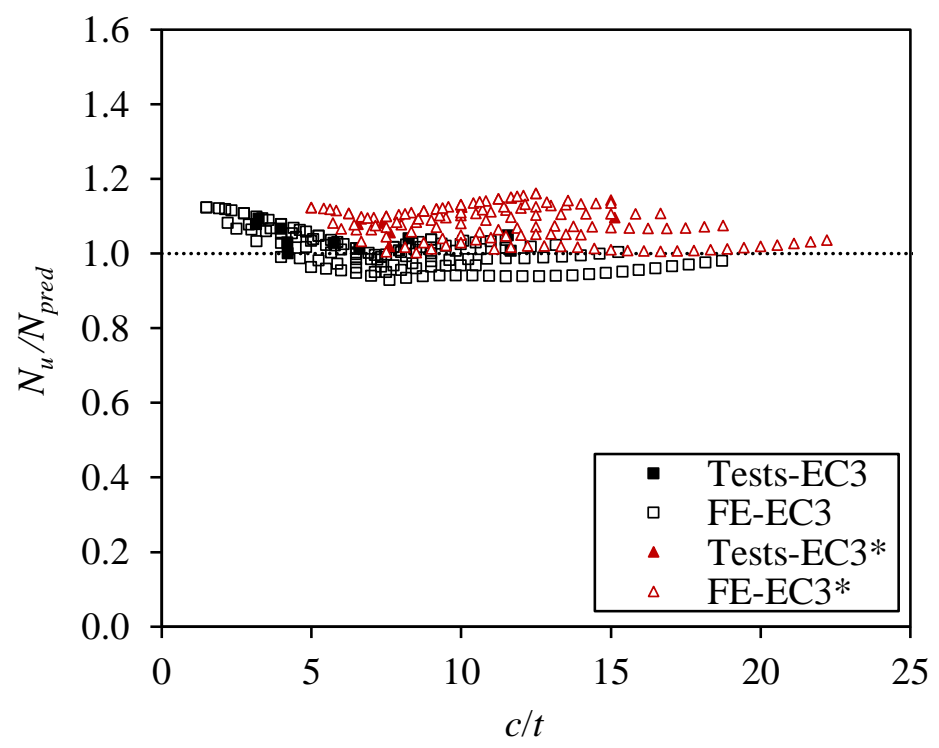

Fig. 16. Comparisons of press-braked S960 UHSS channel section stub column test and FE failure loads with resistance predictions from original and revised EC3 design rules. 


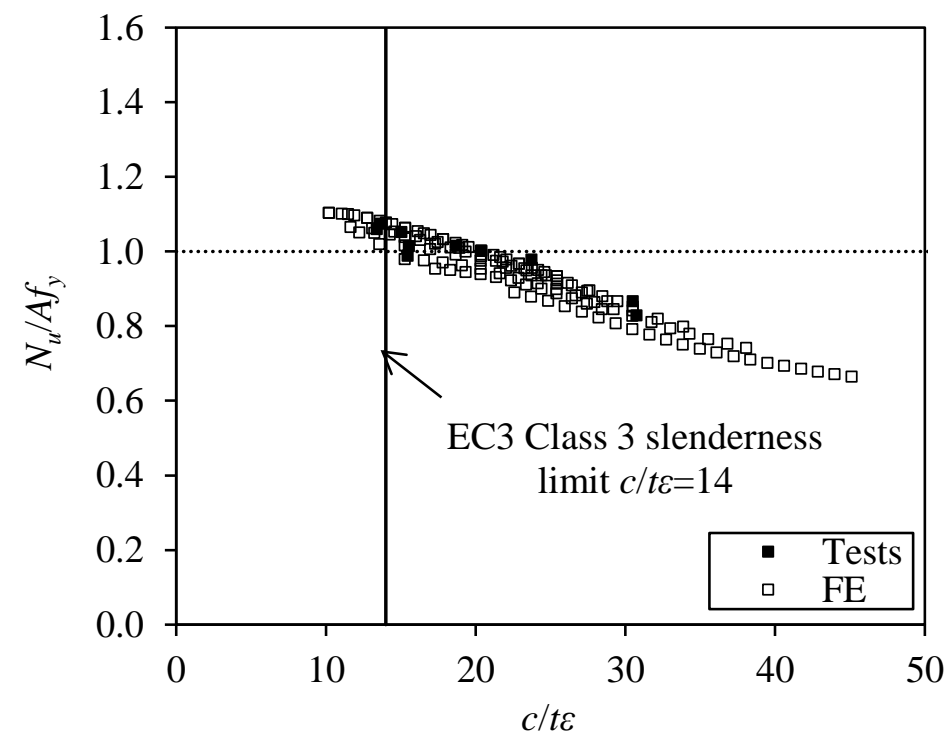

Fig. 17. Assessment of EC3 Class 3 slenderness limit for outstand flanges of channel sections in compression, based on full flange width-to-thickness ratios.

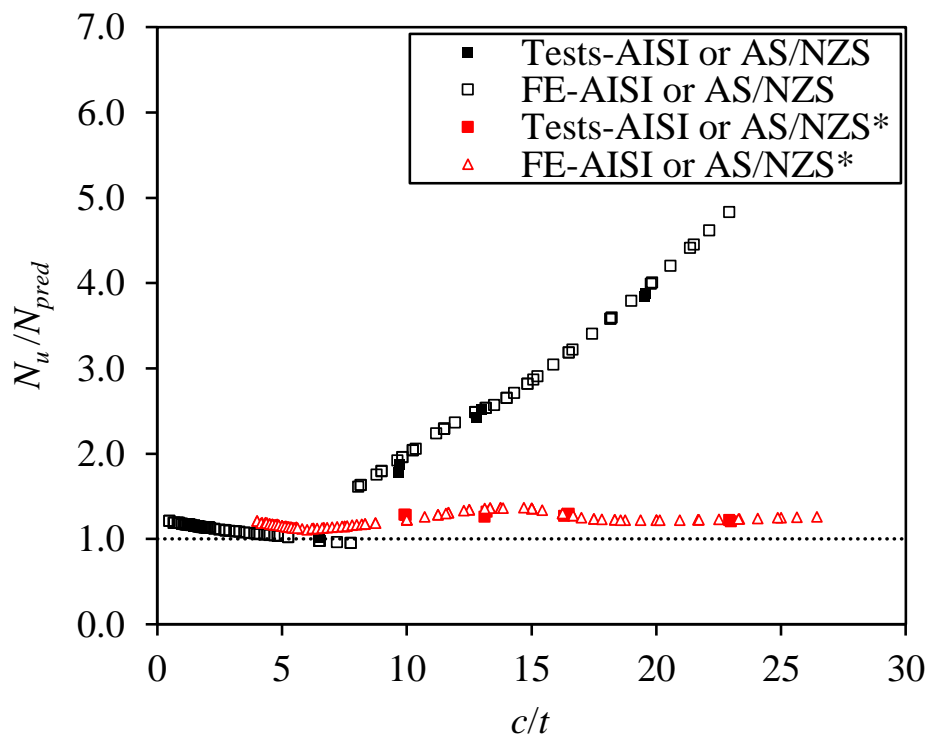

Fig. 18. Comparisons of press-braked S960 UHSS angle section stub column test and FE failure loads with strength predictions from original and revised AISI S100 (or AS/NZS 4600) design rules. 


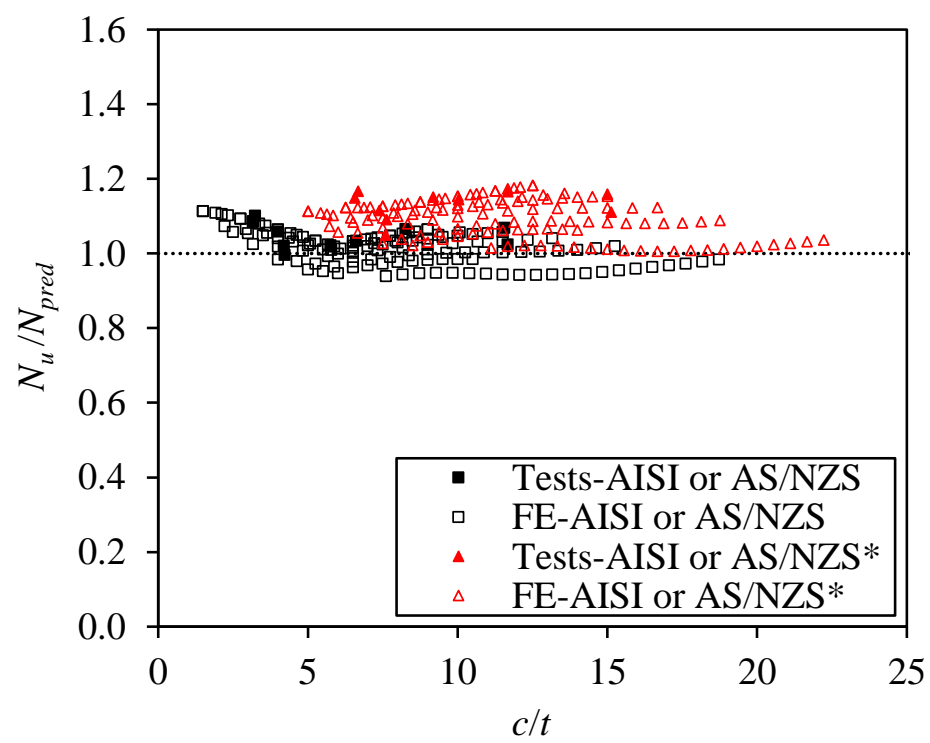

Fig. 19. Comparisons of press-braked S960 UHSS channel section stub column test and FE failure loads with strength predictions from original and revised AISI S100 (or AS/NZS 4600) design rules. 
Table 1. Chemical compositions of structural steel grade S960QL

\begin{tabular}{ccccccccccccccc}
\hline $\mathrm{C}$ & $\mathrm{Si}$ & $\mathrm{Mn}$ & $\mathrm{P}$ & $\mathrm{S}$ & $\mathrm{Cr}$ & $\mathrm{Ni}$ & $\mathrm{Mo}$ & $\mathrm{V}$ & $\mathrm{Ti}$ & $\mathrm{Cu}$ & $\mathrm{Ai}$ & $\mathrm{Nb}$ & $\mathrm{B}$ & $\mathrm{N}$ \\
$(\%)$ & $(\%)$ & $(\%)$ & $(\%)$ & $(\%)$ & $(\%)$ & $(\%)$ & $(\%)$ & $(\%)$ & $(\%)$ & $(\%)$ & $(\%)$ & $(\%)$ & $(\% 0)$ & $(\%)$ \\
\hline 0.16 & 0.21 & 1.25 & 0.09 & 0.01 & 0.20 & 0.05 & 0.59 & 0.39 & 0.02 & 0.01 & 0.47 & 0.15 & 0.01 & 0.02 \\
\hline
\end{tabular}

Table 2. Measured geometric dimensions and initial local geometric imperfections of press-braked S960 UHSS angle section stub column specimens.

\begin{tabular}{|c|c|c|c|c|c|c|c|}
\hline Specimen ID & $\begin{array}{c}L \\
(\mathrm{~mm})\end{array}$ & $\begin{array}{c}B \\
(\mathrm{~mm})\end{array}$ & $\begin{array}{c}t \\
(\mathrm{~mm})\end{array}$ & $\begin{array}{c}r_{i} \\
(\mathrm{~mm})\end{array}$ & $\begin{array}{c}\omega_{f 1} \\
(\mathrm{~mm})\end{array}$ & $\begin{array}{c}\omega_{f 2} \\
(\mathrm{~mm})\end{array}$ & $\begin{array}{c}\omega_{0} \\
(\mathrm{~mm})\end{array}$ \\
\hline A $60 \times 6$ & 149.2 & 60.93 & 6.12 & 15.0 & 0.08 & 0.05 & 0.08 \\
\hline A $60 \times 6-R$ & 148.6 & 60.55 & 6.11 & 15.0 & 0.07 & 0.02 & 0.07 \\
\hline A $80 \times 6$ & 200.1 & 80.69 & 6.15 & 15.0 & 0.10 & 0.03 & 0.10 \\
\hline A $80 \times 6-R$ & 201.0 & 80.32 & 6.08 & 15.1 & 0.08 & 0.04 & 0.08 \\
\hline A $100 \times 6$ & 246.0 & 99.68 & 6.11 & 15.3 & 0.06 & 0.05 & 0.06 \\
\hline A $100 \times 6-R$ & 244.6 & 100.49 & 6.10 & 15.2 & 0.03 & 0.03 & 0.03 \\
\hline A $140 \times 6$ & 350.1 & 140.52 & 6.11 & 15.0 & 0.08 & 0.08 & 0.08 \\
\hline A $140 \times 6-R$ & 349.5 & 140.62 & 6.13 & 14.5 & 0.06 & 0.03 & 0.06 \\
\hline
\end{tabular}

Note: ' $\mathrm{R}$ ' indicates a repeated specimen.

Table 3 Measured geometric dimensions and initial local geometric imperfections of press-braked S960 UHSS channel section stub column specimens.

\begin{tabular}{lccccccccc}
\hline Specimen ID & $\begin{array}{c}L \\
(\mathrm{~mm})\end{array}$ & $\begin{array}{c}B_{f} \\
(\mathrm{~mm})\end{array}$ & $\begin{array}{c}B_{w} \\
(\mathrm{~mm})\end{array}$ & $\begin{array}{c}t \\
(\mathrm{~mm})\end{array}$ & $\begin{array}{c}r_{i} \\
(\mathrm{~mm})\end{array}$ & $\begin{array}{c}\omega_{w} \\
(\mathrm{~mm})\end{array}$ & $\begin{array}{c}\omega_{f 1} \\
(\mathrm{~mm})\end{array}$ & $\begin{array}{c}\omega_{f 2} \\
(\mathrm{~mm})\end{array}$ & $\begin{array}{c}\omega_{0} \\
(\mathrm{~mm})\end{array}$ \\
\hline C $70 \times 40 \times 6$ & 137.1 & 40.43 & 70.66 & 6.06 & 14.8 & 0.01 & 0.04 & 0.05 & 0.05 \\
C $70 \times 40 \times 6-\mathrm{R}$ & 137.2 & 40.37 & 70.01 & 6.16 & 14.8 & 0.01 & 0.02 & 0.01 & 0.02 \\
C $80 \times 45 \times 6$ & 155.6 & 45.68 & 79.95 & 6.00 & 14.5 & 0.03 & 0.01 & 0.01 & 0.03 \\
C $100 \times 45 \times 6$ & 180.5 & 45.67 & 100.33 & 6.19 & 14.8 & 0.02 & 0.05 & 0.02 & 0.05 \\
C $120 \times 45 \times 6$ & 205.4 & 46.43 & 118.77 & 6.11 & 14.5 & 0.07 & 0.07 & 0.03 & 0.07 \\
C $80 \times 55 \times 6$ & 168.1 & 55.64 & 81.08 & 6.06 & 14.8 & 0.05 & 0.03 & 0.02 & 0.05 \\
C $100 \times 60 \times 6$ & 197.6 & 60.18 & 100.92 & 6.00 & 14.5 & 0.04 & 0.00 & 0.03 & 0.04 \\
C $120 \times 70 \times 6$ & 236.4 & 70.09 & 120.37 & 6.00 & 14.5 & 0.03 & 0.02 & 0.03 & 0.03 \\
C $120 \times 90 \times 6$ & 259.5 & 92.26 & 120.06 & 6.10 & 15.0 & 0.04 & 0.04 & 0.06 & 0.06 \\
C $120 \times 90 \times 6-\mathrm{R}$ & 263.1 & 92.35 & 120.63 & 6.16 & 15.0 & 0.03 & 0.03 & 0.01 & 0.03 \\
\hline
\end{tabular}

Note: 'R' indicates a repeated specimen. 
Table 4 Measured tensile flat and corner material properties.

\begin{tabular}{|c|c|c|c|c|c|c|}
\hline Coupon ID & $\begin{array}{c}f_{y} \\
(\mathrm{MPa})\end{array}$ & $\begin{array}{c}f_{u} \\
(\mathrm{MPa})\end{array}$ & $\begin{array}{c}E \\
(\mathrm{GPa})\end{array}$ & $\begin{array}{c}\varepsilon_{u} \\
(\%)\end{array}$ & $\begin{array}{c}\varepsilon_{f} \\
(\%)\end{array}$ & $f_{u} / f_{y}$ \\
\hline A $60 \times 6-\mathrm{L}$ & 928 & 1012 & 209 & 4.3 & 14.4 & 1.09 \\
\hline A $60 \times 6-C$ & 1036 & 1171 & 202 & 2.4 & 10.7 & 1.13 \\
\hline A $140 \times 6-\mathrm{L}$ & 971 & 998 & 203 & 5.9 & 14.6 & 1.03 \\
\hline A $140 \times 6-L-R$ & 983 & 1015 & 210 & 5.4 & 13.5 & 1.03 \\
\hline C $70 \times 40 \times 6-W$ & 935 & 1000 & 214 & 4.5 & 14.3 & 1.07 \\
\hline C $70 \times 40 \times 6-F$ & 927 & 1021 & 203 & 5.1 & 13.3 & 1.10 \\
\hline C $120 \times 90 \times 6-W$ & 969 & 994 & 208 & 4.7 & 13.9 & 1.03 \\
\hline C $120 \times 90 \times 6-F$ & 963 & 1001 & 200 & 6.6 & 14.7 & 1.04 \\
\hline C $120 \times 90 \times 6-C$ & 1030 & 1177 & 206 & 2.5 & 10.7 & 1.14 \\
\hline VS & 982 & 1011 & 208 & 5.1 & 12.3 & 1.03 \\
\hline
\end{tabular}

Note: 'R' indicates a repeated coupon specimen.

Table 5 Summary of press-braked S960 UHSS angle section stub column test results.

\begin{tabular}{|c|c|c|c|c|c|}
\hline Specimen ID & $N_{u, t e s t}(\mathrm{kN})$ & $\delta_{u}(\mathrm{~mm})$ & $N_{u, t e s t} / N_{E C 3}$ & $N_{u, \text { test }} / N_{\text {AISI }}$ & $N_{u, \text { test }} / N_{A S / N Z S}$ \\
\hline A $60 \times 6$ & 637 & 1.07 & 1.22 & 1.01 & 1.01 \\
\hline A $60 \times 6-R$ & 636 & 1.11 & 1.22 & 1.02 & 1.02 \\
\hline A $80 \times 6$ & 737 & 1.01 & 1.22 & 1.78 & 1.78 \\
\hline A $80 \times 6-R$ & 757 & 1.04 & 1.28 & 1.87 & 1.87 \\
\hline A $100 \times 6$ & 794 & 1.18 & 1.24 & 2.43 & 2.43 \\
\hline A $100 \times 6-R$ & 806 & 1.11 & 1.27 & 2.51 & 2.51 \\
\hline A $140 \times 6$ & 826 & 2.24 & 1.19 & 3.84 & 3.84 \\
\hline A $140 \times 6-R$ & 835 & 2.51 & 1.20 & 3.87 & 3.87 \\
\hline Mean & & & 1.23 & 2.29 & 2.29 \\
\hline $\mathrm{COV}$ & & & 0.025 & 0.487 & 0.487 \\
\hline
\end{tabular}

Table 6. Summary of press-braked S960 UHSS channel section stub column test results.

\begin{tabular}{llrrrc}
\hline Specimen ID & $N_{u, \text { test }}(\mathrm{kN})$ & $\delta_{u}(\mathrm{~mm})$ & $N_{u, \text { tes }} / N_{E C 3}$ & $N_{u, \text { tes }} / N_{\text {AISI }}$ & $N_{u, \text { tes }} / N_{A S N Z S}$ \\
\hline C $70 \times 40 \times 6$ & 791 & 4.291 & 1.09 & 1.10 & 1.10 \\
C $70 \times 40 \times 6-\mathrm{R}$ & 788 & 5.345 & 1.08 & 1.09 & 1.09 \\
C $80 \times 45 \times 6$ & 857 & 4.512 & 1.03 & 1.02 & 1.02 \\
C $100 \times 45 \times 6$ & 1041 & 5.217 & 1.07 & 1.06 & 1.06 \\
C $120 \times 45 \times 6$ & 1085 & 4.866 & 1.00 & 1.00 & 1.00 \\
C $80 \times 55 \times 6$ & 989 & 4.717 & 1.03 & 1.02 & 1.02 \\
C $100 \times 60 \times 6$ & 1137 & 3.833 & 1.01 & 1.03 & 1.03 \\
C $120 \times 70 \times 6$ & 1332 & 2.833 & 1.04 & 1.06 & 1.06 \\
C $120 \times 90 \times 6$ & 1437 & 2.681 & 1.05 & 1.07 & 1.07 \\
C $120 \times 90 \times 6-\mathrm{R}$ & 1359 & 3.222 & 1.01 & 1.02 & 1.02 \\
\hline Mean & & & 1.04 & 1.05 & 1.05 \\
COV & & & 0.030 & 0.032 & 0.032 \\
\hline
\end{tabular}


Table 7. Comparison of S960 UHSS angle section stub column FE and test failure loads for varying initial local geometric imperfection amplitudes.

\begin{tabular}{|c|c|c|c|c|c|}
\hline \multirow[b]{2}{*}{ Specimen ID } & \multicolumn{5}{|c|}{$N_{u, F E} / N_{u, t e s t}$} \\
\hline & $\begin{array}{c}\text { Measured value } \\
\omega_{\beta}\end{array}$ & $t / 100$ & $t / 50$ & $t / 25$ & $t / 10$ \\
\hline A $60 \times 6$ & 1.02 & 1.02 & 1.02 & 1.01 & 1.00 \\
\hline A $60 \times 6-R$ & 1.02 & 1.02 & 1.01 & 1.00 & 0.99 \\
\hline A $80 \times 6$ & 1.07 & 1.08 & 1.07 & 1.06 & 1.05 \\
\hline A $80 \times 6-R$ & 1.03 & 1.03 & 1.01 & 1.01 & 1.00 \\
\hline A $100 \times 6$ & 1.06 & 1.06 & 1.05 & 1.03 & 1.01 \\
\hline A $100 \times 6-R$ & 1.03 & 1.03 & 1.02 & 1.01 & 0.99 \\
\hline A $140 \times 6$ & 1.01 & 1.02 & 1.02 & 1.02 & 1.02 \\
\hline A $140 \times 6-R$ & 1.01 & 1.01 & 1.01 & 1.01 & 1.01 \\
\hline Mean & 1.03 & 1.03 & 1.03 & 1.02 & 1.01 \\
\hline $\mathrm{COV}$ & 0.022 & 0.022 & 0.022 & 0.019 & 0.020 \\
\hline
\end{tabular}

Table 8. Comparison of S960 UHSS channel section stub column FE and test ultimate loads for varying initial local geometric imperfection amplitudes.

\begin{tabular}{lccccc}
\hline \multirow{2}{*}{ Specimen ID } & \multicolumn{5}{c}{$N_{u, F E} / N_{u, \text { test }}$} \\
\cline { 2 - 4 } & $\begin{array}{c}\text { Measured value } \\
\omega_{0}\end{array}$ & $t / 100$ & $t / 50$ & \multirow{2}{*}{$t / 25$} & \multirow{2}{*}{$t / 10$} \\
\hline C $70 \times 40 \times 6$ & 1.07 & 1.07 & 1.06 & 1.05 & 1.04 \\
C $70 \times 40 \times 6-\mathrm{R}$ & 1.09 & 1.09 & 1.08 & 1.07 & 1.03 \\
C $80 \times 45 \times 6$ & 1.10 & 1.09 & 1.09 & 1.08 & 1.05 \\
C $100 \times 45 \times 6$ & 1.04 & 1.04 & 1.04 & 1.03 & 1.00 \\
C $120 \times 45 \times 6$ & 1.08 & 1.08 & 1.07 & 1.06 & 1.03 \\
C $80 \times 55 \times 6$ & 1.06 & 1.06 & 1.05 & 1.04 & 1.01 \\
C $100 \times 60 \times 6$ & 1.04 & 1.03 & 1.02 & 1.01 & 0.99 \\
C $120 \times 70 \times 6$ & 1.00 & 1.00 & 0.99 & 0.98 & 0.95 \\
C $120 \times 90 \times 6$ & 1.03 & 1.02 & 1.01 & 1.00 & 0.96 \\
C $120 \times 90 \times 6-\mathrm{R}$ & 1.06 & 1.06 & 1.05 & 1.04 & 1.03 \\
\hline Mean & 1.06 & 1.05 & 1.05 & 1.04 & 1.01 \\
COV & 0.028 & 0.029 & 0.030 & 0.031 & 0.034 \\
\hline
\end{tabular}


Table 9. Cross-section geometric dimensions selected for parametric studies.

\begin{tabular}{|c|c|c|c|c|}
\hline $\begin{array}{l}\text { Cross-section } \\
\text { type }\end{array}$ & $\begin{array}{c}t \\
(\mathrm{~mm})\end{array}$ & $\begin{array}{c}R_{i} \\
(\mathrm{~mm})\end{array}$ & $\begin{array}{c}B_{w} \\
(\mathrm{~mm})\end{array}$ & $\begin{array}{c}B \text { or } B_{f} \\
(\mathrm{~mm})\end{array}$ \\
\hline \multirow{7}{*}{$\begin{array}{l}\text { Angle } \\
\text { sections }\end{array}$} & 4 & 10 & --- & $20,25,30,35,40,45,50,55,60,65,70$ \\
\hline & 6 & 15 & --- & $30,40,50,60,70,80,90,100,110,120,130$ \\
\hline & 8 & 20 & --- & $50,60,70,80,90,100,110,120,130,140,150$ \\
\hline & 10 & 25 & --- & $\begin{array}{c}50,52,54,56,58,60,62,64,66,68,70,72,74,76,78 \\
80,82\end{array}$ \\
\hline & 12 & 30 & --- & $\begin{array}{c}48,50,52,54,56,58,60,62,64,66,100,120,140,160, \\
180,200,220,240,260,280,300\end{array}$ \\
\hline & 14 & 35 & --- & $\begin{array}{c}66,68,70,72,74,76,78 \\
150,172,194,216,238,260,282,304,326,348,370\end{array}$ \\
\hline & 16 & 40 & --- & $\begin{array}{c}70,72,74,76,78,80,82,84,86,88,90 \\
160,185,210,235,260,285,310,335,360,385,410\end{array}$ \\
\hline \multirow{8}{*}{$\begin{array}{l}\text { Channel } \\
\text { sections }\end{array}$} & 8 & 20 & 180 & $\begin{array}{c}60,65,70,75,80,85,90,95,100,105,110,115,120 \\
125,130,135,140,145,150\end{array}$ \\
\hline & 10 & 25 & 180 & $\begin{array}{c}60,65,70,75,80,85,90,95,100,105,110,115,120 \\
125,130,135,140,145,150\end{array}$ \\
\hline & 12 & 30 & 180 & $\begin{array}{c}60,65,70,75,80,85,90,95,100,105,110,115,120 \\
125,130,135,140,145,150\end{array}$ \\
\hline & 9 & 22.5 & 240 & $\begin{array}{c}100,105,110,115,120,125,130,135,140,145,150 \\
155,160,165,170,175,180,185,190,195,200\end{array}$ \\
\hline & 10 & 25 & 240 & $85,90,95,100,105,110,115,120,125,130,135,140$ \\
\hline & 12 & 30 & 240 & $\begin{array}{c}80,90,100,110,120,130,140,150,160,170,180,190, \\
200\end{array}$ \\
\hline & 14 & 35 & 240 & $80,90,100,110,120,130,140,150,160,170,180,190$ \\
\hline & 16 & 40 & 240 & $\begin{array}{c}80,90,100,110,120,130,140,150,160,170,180,190, \\
200\end{array}$ \\
\hline
\end{tabular}


1 Table 10. Comparisons of press-braked S960 UHSS angle section stub column test and FE failure

2 loads with predicted compression resistances.

\begin{tabular}{|c|c|c|c|c|c|c|c|}
\hline \multirow[t]{2}{*}{$\begin{array}{c}\text { Section } \\
\text { type }\end{array}$} & & \multicolumn{2}{|c|}{$N_{u} / N_{E C 3}$} & \multicolumn{2}{|c|}{$\begin{array}{l}N_{u} / N_{A I S I} \text { or } \\
N_{u} / N_{A S / N Z S}\end{array}$} & \multicolumn{2}{|c|}{$\begin{array}{l}N_{u} / N_{A I S I^{*}} \text { or } \\
N_{u} / N_{A S / N Z S^{*}}\end{array}$} \\
\hline & $\begin{array}{l}\text { Section } \\
\text { classification }\end{array}$ & $\begin{array}{l}\text { Non- } \\
\text { slender }\end{array}$ & $\begin{array}{c}\text { Slend } \\
\text { er }\end{array}$ & $\begin{array}{l}\text { Non- } \\
\text { slender }\end{array}$ & $\begin{array}{c}\text { Slend } \\
\text { er }\end{array}$ & $\begin{array}{l}\text { Non- } \\
\text { slender }\end{array}$ & $\begin{array}{c}\text { Slend } \\
\text { er }\end{array}$ \\
\hline \multirow{4}{*}{ Angle } & No. of test & 0 & 8 & 2 & 6 & 0 & 8 \\
\hline & No. of FE & 36 & 80 & 69 & 47 & 41 & 75 \\
\hline & Mean & 1.14 & 1.20 & 1.09 & 2.79 & 1.16 & 1.24 \\
\hline & $\mathrm{COV}$ & 0.016 & 0.066 & 0.060 & 0.310 & 0.020 & 0.058 \\
\hline
\end{tabular}

3

4

5

6

7

Table 11. Comparisons of press-braked S960 UHSS channel section stub column test and FE failure loads with predicted compression resistances.

\begin{tabular}{cccccccccc}
\hline $\begin{array}{c}\text { Section } \\
\text { type }\end{array}$ & \multicolumn{3}{c}{$N_{u} / N_{E C 3}$} & \multicolumn{2}{c}{$N_{u} / N_{E C 3^{*}}$} & \multicolumn{2}{c}{$N_{u} / N_{A I S I}$ or } \\
$N_{u} / N_{A S / N Z S}$ & \multicolumn{2}{c}{$N_{u} / N_{A I S I^{*} \text { or }}$} \\
\hline \multirow{4}{*}{ Channel $/ N_{A S / N Z S^{*}}$} \\
& Section & Non- & Slen & Non- & Slen & Non- & Slen & Non- & Slen \\
classification & slender & der & slender & der & slender & der & slender & der \\
& No. of test & 7 & 3 & 2 & 8 & 6 & 4 & 0 & 10 \\
& No. of FE & 60 & 68 & 17 & 111 & 45 & 83 & 7 & 121 \\
& Mean & 1.03 & 0.99 & 1.09 & 1.08 & 1.04 & 1.01 & 1.10 & 1.10 \\
& COV & 0.048 & 0.03 & 0.023 & 0.043 & 0.042 & 0.038 & 0.020 & 0.046 \\
\hline
\end{tabular}

